\title{
The Tale of Post-Arab Spring in Egypt: The Struggle of Civil Society Against a JANUS-FACED STATE ${ }^{1}$
}

\author{
MOHAMED 'ARAFA \\ "The Middle East is one of the hardest-hearted areas in the world. It has \\ always been fought over, and peace has only reigned when a major \\ power has established firm influence and shown that it would maintain \\ its will ... Force, or perhaps force and bribery, are the only things that \\ will be respected. It is very sad, but we had all bet-ter recognize it."
}

$\sim$ Winston Churchill

\section{INTRODUCTION AND OVERVIEW}

In early 2011, the so-called "Arab Spring" had begun in Tunisia, and after the downfall of the Zine El'Abidine bin'Ali régime, a huge wave of revolutionary movements across Egypt led to the resignation of the autocratic leader President Mohammad Hosni Mubarak and his removal from power. ${ }^{4}$ Since then, the country has gone through several riotous and unstable years, resulting in numerous elections, uncertain governing authority, and an unclear legal framework. ${ }^{5}$ In 2013, the al-qwaat al-moselahh (military), along with the

1. This article was accepted to be presented at the LAW AND Society ANNUAL MeETing, Conference at the University of Washington School of Law in Seattle on a panel titled "Law and Revolution: The Arab Spring and Beyond" on May 28, 2015.

2. Assistant Professor of Law at Alexandria University Faculty of Law (Egypt); Adjunct Professor of Law at Indiana University Robert H. McKinney School of Law (USA). Ph.D., Indiana University Robert H. McKinney School of Law (2013); LL.M., University of Connecticut School of Law (2008); LL.B., Alexandria University School of Law (2006). Recently, he has been named to the editorial board of the Arab Law Quarterly in London as a "Managing Editor." In April/October 2016, he was a Visiting Professor of Law at the University of Brasília School of Law. Of course, all errors remain the author. For any comments or questions, please contact the author atmarafa@iupui.edu.

3. See Anthony Montague Browne, Long Sunset: Memoirs of Winston Churchill's Last Private Secretary (London 1995), at 166-167.

4. See Mohamed 'Arafa, Towards a Culture for Accountability: A New Dawn for Egypt, 5 Phoenix L. REV. 1 (2011), at 1-2 (“[A] spontaneous popular and peaceful revolution" arose out of a civil society, without a charismatic leader to shepherd it nor any noticeable centralized direction. If not for the violent provocations of pro-regime hired thugs, "it would have been one of the most significant, peaceful manifestations of a people's desire for change" in modern history. "The fact that Egyptian civil society, cutting across generational, religious, gender, and economic lines without a charismatic leader, has been able to organize itself at the grassroots level . . in the face of a strong [r] egime, evidences people-power." The vast array of people "all standing up for the same values and principles" attests the social and political transformation in Egypt and other areas of the Arab world").

5. Id. at 4-5. See also M. Cherif Bassiouni, The Fight for Democracy in Egypt's Liberation

http://doi.org/18060/7909.0046 
Egyptian people, exiled the Islamist dictator President Mohammad Morsi from office in a popular coup, approved and enacted a new constitution by a referendum in January 2014, and conducted a fair, transparent presidential election in 2014, resulting in the election of 'Abdel Fattah el-Sisi, the former Defense Minister and Commander -in-Chief, as the President of the Republic. ${ }^{6}$

On this subject, it should be noted that prior to and since the 2011 uprising, Egyptian civil society has been governed by various constitutional and legal provisions, including the de facto Law on Non-Governmental Organizations ("NGOs") No. 84 of 2002 and its regulations, replaced recently by Law No. 70 of 2017 for Regulating the Work of Associations and Other Institutions Working in the Field of Civil Work governed by the Ministry of Social Affairs. ${ }^{7}$ According to this new law, all NGOs are prohibited from conducting activities that "harm national security, public order, public morality, or public health," ambiguous and broad concepts that can be abused to restrain legal activity. The bill creates a National Authority for the Regulation of Foreign Non-Governmental Organizations that comprises representatives of Egypt's top national security

Square: Background Paper, MideAst Reports (Feb. 15, 2011), https://mideastreports.wordpress.com/2011/02/15/the-fight-for-democracy-in-egypt $\% \mathrm{E} 2 \% 80 \% 99 \mathrm{~s}$ liberation-square/ (last visited Sep. 4, 2016).

6. See Egypt Military Unveils Transitional Roadmap: Military Commander-in-Chief AbdelFattah el-Sisi Dismisses Egypt's President Amid Massive Opposition Protests, Unveils Roadmap for Country's Political Future, Aharmonline (July 3, 2013), http://english.ahram.org.eg/NewsContentPrint/1/0/75631/Egypt/0/Egypt-militaryunveilstransitional-roadmap.aspx [http://perma.cc/HKL6-P8ZC]; See also Stephen Kalin and Maggie Fick, Egypt's Sisi Wins Election, Faces Economic Challenges, Reuters, May 29, 2014, http://www.reuters.com/article/2014/05/29/us-egypt-election-idUSKBN0E70D720140529 ("Former Egyptian Army Chief Abdel Fattah al-Sisi won a landslide victory in a presidential election . . .he needs to fix the economy and face down an Islamist insurgency. Sisi won 93.3 percent of votes cast, judicial sources said, with most ballots counted after three days of voting . ..”); For further details on the definition of the popular coup, see Mohamed 'Arafa, Whither Egypt? Against Religious Fascism and Legal Authoritarianism: Pure Revolution, Popular Coup, or a Military Coup d'état? 24 IND. INT'L. \& COMP. L. REV. 4 (2014), at 874-877 (“Given the absence of a legally and constitutionally adequate instrument to impeach the sitting President [and the absence of an independent Parliament], millions of Egyptians turned out to protest against him, asking that he respectfully step-down. At the same time, a national movement called tamarod [repel] collected more than twenty-two million petitions seeking the President's resignation and requesting earlier elections, principally because of the political failures that predicated the January 2011 uprisings. In addition, the military submitted to the rule of law because it did not take over power, but promised to implement a road map towards real democracy during this 'transitional period,' one that included a new constitution and fresh parliamentary and presidential elections. Accordingly, the military installed the Chief Justice of the Egyptian Supreme (High) Court to serve as a temporary President until new elections were held").

7. See Law on Associations No.84/2002, Al-Jarida Al-Rasmiyya [The Official GAZETte], June 5, 2002 (Egypt), http:/www.bu.edu/bucflp/files/2012/01/Law-onNongovernmental-Organizations-Law-No.-84-of-2002.pdf. 
bodies - the General Intelligence Directorate and the Defense and Interior Ministries - as well as representatives from the Foreign Affairs Ministry and the Central Bank of Egypt. ${ }^{8}$ The authority will oversee the work of NGOs, including any funding or cooperation between Egyptian associations and any foreign entity and prohibits any Egyptian government body from making agreements with NGOs without the authority's approval. ${ }^{9}$

The law strictly controls the funding of NGOs. It states that "associations must obtain permission from the authority thirty days in advance to receive donations from Egyptian entities or individuals inside Egypt and must inform the Social Solidarity Ministry upon the receipt of such funds." ${ }^{10}$ The law further states that "associations may receive funding or grants from foreign entities inside Egypt or Egyptian or foreign entities outside Egypt as long as the authority is notified within 30 days of receipt. The authority then has the right to reject the funding within a 60 -day period following its notification. Associations may not use these funds within the 60-day review period." 1

To Egyptians, this new bill means that restricting civil society to this extent averts a path for Egyptian citizens to peacefully elicit dissent, hold the government accountable for human rights transgressions, and access human development initiatives at a time of economic difficulties. By curtailing civil society, the government has made it more complicated for NGOs to respond to social goods and needs that at times can lead to unrest, such as recent increases in the price of all commodities. Increased state control of Egyptian NGOs results in opacity surrounding security threats and terror attacks and gives perpetrators the opportunity to shape the narrative of the struggle between the state and violent extremists. The new law has been severely criticized by human rights organizations, who argue that it cripples the work of NGOs, upsurges their administrative burdens and sets forth draconian punitive measures against the groups. ${ }^{12}$ Observers say the law confines the activity of NGOs to accomplish only

8. Law No. 70 of 2017 (for Regulating the Work of Associations and Other Institutions Working in the Field of Civil Work) Al-Jarida Al-Rasmiyya [The OfFicial GazeTtE], May 29, 2017 (Egypt).

9. Id., at art. 8

10. Id., at art. 87

11. Id.

12. See Egypt's Sisi Approves Controversial NGO Law: The Bill Restricts NGO Activity to Developmental and Social Work and Introduces Jail Terms for Non-compliance, ALJAZEERA, May 29, 2017, http://www.aljazeera.com/news/2017/05/egypt-sisi-approves-controversial-ngo-law170529182720099.html ("Egypt's President Abdel Fattah el-Sisi has signed into law a contentious new bill to regulate non-governmental organizations, making it harder for charities to operate. The measure restricts NGO activity to developmental and social work and introduces jail terms of up to five years for non-compliance. Under the law, foreign non-governmental groups will have to pay up to $\$ 16,500$ to start working in Egypt and renew their permit on a regular basis, a human rights lawyer said. "The law eliminates civil society in Egypt, whether human rights or development organizations," No organization can carry out or publish the results of a study or survey without prior permission from the state. Those who violate the law could receive up to five years in jail and 
those developmental activities needed by the Egyptian government and enforces draconian sanctions on any NGO that breaches the government's provisions; the observers say this is equivalent to a breach of human rights. ${ }^{13}$

The new statute also bans NGOs from carrying out field activities, conducting opinion polls, or cooperating with any international bodies without obtaining the required approvals from a newly established body. ${ }^{14}$ For example, Article 2 of this law requires many NGOs to regularize their situation in accordance with its provisions in terms of registration, the announcement of sources of funding, and types of activities within one year of its entering into force. ${ }^{15}$ The article designated that any NGO that fails to do so shall be dissolved by a court order, its assets shall revert to the Social Fund for Development - a government fund for the support of NGOs - and all of its activity carried out in violation with the provisions of this article shall be suspended. ${ }^{16}$

Notwithstanding the vastly restrictive spirit of these legal norms, Egyptian civil society in both public and private sectors plays a fundamental role particularly in raising social awareness of political, social, and economic civil rights among the general public. ${ }^{17}$ Thus, it may seem incompatible that so many civil society organizations and NGOs can exist in a country whose laws are among the most obstructive of free speech and expression. However, the impact of this constrained legal framework has not been to entirely bar civil society, but rather, to give massive discretionary powers to the Ministry of Social Solidarity. ${ }^{18}$

fines of up to one million Egyptian pounds (more than \$55,000). The law - which was criticized by the United Nations and New York-based Human Rights Watch - requires for a "national authority" including army and intelligence representatives to oversee the foreign funding of Egyptian non-governmental organizations and the activities of foreign non-governmental organizations"). See also, http://www.almasryalyoum.com/news/details/1141060.

13. Id. See also: http://www.al-monitor.com/pulse/originals/2017/06/egypt-ngo-law-ratifiedsisi-crippling-restrictions-freedom.html\#ixzz4rgDjOcBY

14. Id.

15. Law No. 70, 2017, supra note 8, at Art. 2

16. Id.

17. See generally Julie Fisher, Nongovernment's: NGOs and the Political DEVElOPMENT OF THE THIRD WORLD (1997) ("Nongovernment's details the influence these organizations have had on world political systems and the hope they bring to the possibility for sustainable development"). See also Roland Hoksbergrn, Give Them a Fish, Teach Them to Fish or Organize a Fishing Club? NGOs, Civil Society, and Economic Development, 34 FAITH \& ECONOMICS J. (1999), https://www.gordon.edu/ace/pdf/Hoksbergen=F\&E34.pdf.

18. See H.A. Hellyer, The End of an Era for Egypt's NGOs, AlarabiYa News, (Nov. 14, 2014), http://english.alarabiya.net/en/views/news/middle-east/2014/11/10/The-end-of-an-era-forEgypt-s-NGOs.html ("Egypt's authorities since Mubarak's resignation and every successive administration since, have been trying to establish a new legal regime for NGOs. Each time, human rights organizations and civil rights groups have expressed concerns that the suggested legal drafts will simply restrict the space for NGOs, rather than regulate them in a fair manner. Each time, they've drawn attention to Egypt's international legal commitments and the international community has often agreed. It is no wonder that at the recent Universal Periodic Review at the 
Practically speaking, the Social Solidarity apparatus' authority has been used to combat organizations and individuals that may have crossed the government's "red lines", as public folks have no rights to talk about their fundamental rights by demanding social reform, better governance, and political liberalization. ${ }^{19}$

Since the 2011 revolts, civil society groups and NGOs are increasingly required to operate in a climate of control and intimidation. ${ }^{20}$ For instance, Mubarak's administration severely circumscribed one of the main constitutional public freedoms rights - the freedom of association and expression-using a multifaceted set of entangling laws, decrees, and emergency powers to suffocate the exercise of that right, including restricting the formation of new political parties, trade unions, and associations. ${ }^{21}$

By international human rights standards, membership in an unrecognized organization does not amount per se to a criminal offense. ${ }^{22}$ The only restriction imposed is on associations that openly call for violence or terrorist activities. ${ }^{23}$ The wording of the Egyptian criminal code's provisions is much more extensive and contains language that forbids reasonable non-violent political activity and

United Nations..., the subject of NGOs and the reduction of public space for them to operate was raised many times").

19. Ola Kubbara, NGOs Lose Ground in Sisi's Egypt, OpenDemocracy, (Oct. 21, 2014), https://www.opendemocracy.net/arab-awakening/ola-kubbara/ngos-lose-ground-in-sisi\%27s-egypt ("NGOs in Egypt did not expect to have fewer freedoms under Sisi's presidency. But regressive laws and regulations governing them are now being reinforced. Shortly after Sisi's election, the Ministry of Social Affairs requested all Egyptian NGOs to get registered under Law 84/2002. This law undermines the already limited margin permitted for NGO activities and allows for more restrictions and regulations on establishing them").

20. Nourhan Fahmy, What happened to Egypt's NGOs?, Daily News EgYPT, (Nov. 24, 2014), https://www.google.com/webhp? sourceid=chrome-instant\&ion=1\&espv=2\&ie=UTF$8 \# \mathrm{q}=$ egypt\%20ngo ("The current legal situation in Egypt for non-governmental organizations (NGOs) is difficult . . . Clear and targeted measures are being taken against human rights organizations and those working for them . . . Law 84/2002 makes NGOs vulnerable to registration denial and harsher penalties for non-compliance with funding and activity regulations. Despite the time that has since elapsed, the government has yet to take action on the matter, creating a sense of uncertainty about the future for many of Egypt's NGOs").

21. See, e.g., Article 98, added by Law No. 635 of 1954 (Providing for a maximum 10-years sentence for anyone who "establishes an organization or association whose goal is to overthrow the political or social system of the country, or for the dominance of one social class over another or for an end to the economic system . . . or for the incitement to any of the aforementioned or the use of force or terrorism or any other illegitimate method in order to achieve this" and a sentence of five years for all those who "join one of these organizations mentioned in the previous paragraphs" and a sentence of one year to all those who "communicate directly or indirectly with such organizations").

22. Fahmy, supra note 20.

23. See generally Lee Swepston, Human Rights Law and Freedom of Association: Development through ILO Supervision, 137 INT'L. LABOUR REV. 2, 174-78 (1998). 
organizing. $^{24}$

In this respect, several transnational agreements, such as the International Covenant on Civil and Political Rights ("ICCPR"), which Egypt ratified in 1982, and the African Charter on Human and People's Rights ("ACHPR"), conflict with Egypt's criminal provisions. Both the ICCPR and the ACHPR preclude bans on non-violent political activities and guarantee citizens the right to participate in the conduct of public affairs, either directly or indirectly through freely selected representatives, and the right to vote and to be elected in free and fair periodic elections. ${ }^{25}$ Based on international rules, the Human Rights Committee stated that "the right to freedom of association, including the right to form and join organizations and associations concerned with political and public affairs, is an essential adjunct to the rights protected by Article 25," and underscored the right of participation in public affairs including the right to vote. ${ }^{26}$ Egypt's current NGO statute interferes with this essential right by permitting governmental authorities to interfere and hinder the registration process, governance, and operation of NGOs, as well as to encumber the right of the citizens to form and operate independent associations. ${ }^{27}$

Against this backdrop, this Article examines the political and legal ramifications of Egypt's efforts to contain opposition movements in civil society and presents practical solutions to this socio-legal puzzle. Part One has examined the dual policy strategy on curtailing the NGOs and civil society activities, which may lead to opposition. Part Two discusses the following topics: the extent to which framing strategies by the government and public authorities are crucial to achieve these goals; the consequences of these strategies for civil society; and activist groups' responses to the recent crackdown on free speech and expression. Part Three highlights the contemporary institutional and legal framework of NGO operations and explores how the current government justifies its persecution of activities and its threats against independent organizations.

24. See Law No. 58 of 1937 (Egyptian Penal Code) (reformed in 1952), Al-Jarida AlRasmiyya [The Official Gazette], (Egypt), at arts. 98 \& 80(d).

25. See The International Covenant on Civil and Political Rights, (opened for signature Dec. 19, 1966, 999 U.N.T.S. 171 and entered into force Mar. 23, 1976), http://treaties.un.org/Pages/ViewDetails.aspx?src=TREATY\&mtdsg_no=IV 9\&chapter=4\&lang=en; see THE AfricAn [BANJul] CHARTER ON HuMAN AND PEOPLES' Rights, (adopted June 27, 1981, OAU Doc. CAB/LEG/67/3 rev. 5, 21 I.L.M. 58 (1982) and entered into force Oct. 21, 1986), http://www.hrcr.org/docs/Banjul/afrhr.html (last retrieved Sep. 4, 2016).

26. See Human Rights Committee, General Comment 25 (57), General Comments under Article 40, para. 4, of the International Covenant on Civil and Political Rights, adopted by the Committee at its 1510 th meeting, U.N. Doc. CCPR/C/21/Rev.1/Add.7; para. 27 (1996).

27. See M. Arafa, Egypt between Fear and Reform in its Second Revolution: The Failure to Protect the Fundamental Human Rights Over and Over Again, 7 PHoEnIX L. Rev. 149, 164-172 (2013) ("This law infringes the guarantees provided under international law for free association"). See also Negad Al-Bora'I, Al-Maqsala wa Al-TAnur: Hurrayyat Al-TA`Bir fi Misr 20022003: Al-Mushkilat wa Al-Hulul [FreEdom of Expression In EGypt 2002/2003: Problems AND SOLUTIONS] (2004), at 495-502 (on file with author). 
Finally, the Article concludes that the success or failure of Egypt will have a major impact not only on the Middle Eastern region, but on the world, because Egypt is a cornerstone of the Middle East and North African regions. Egypt's current economic, social, and political challenges are complex, and no single political actor or force can handle these problems solely. Political activism has a critical role to play in civil society, as illustrated by recent events in Egypt and around the world. Egypt's Arab Spring rebellions gave rise to change - and legal and political chaos with it. This turmoil must be remedied by restructuring and remodeling laws, by strengthening a sense of community in Arab Middle Eastern nations, by embracing political activism, by empowering NGOs' free operations, and by advocating for human rights. As long as the political and legal environment in Egypt discourages NGOs and the international assistance, Egypt will be deprived of the benefits and welfares that are vital to its democracy.

\section{PART TWO: ACTIVISM, NGOS, AND THE LAW IN POST-MUBARAK AND MORSI EGYPT}

Recent transitions across the Middle East and North African ("MENA") region do not fit typical theoretical forms of regime changes experienced in the former Soviet Union during the post-Cold War 1990s ${ }^{28}{ }^{28}$ Common wisdom before the end of the Cold War assumed that non-profit organizations played a critical role in serving as a catalyst for political and institutional change, but also underscored that governments, mainly in Africa, were quick to use the power of these organizations without allowing them a commensurate platform to advocate for political pluralism. ${ }^{29}$ Political chaos and a large number of perplexing regional shifts with questionable results vis-à-vis democratization goals in the 1990s incited a critique of the transition models. Carothers said:

It is time for the democracy-promotion community to discard the transition paradigm. . . . It does mean, however, that democracy promoters should approach their work with some very different assumptions. They should start by assuming that what is often thought of as an uneasy, precarious middle ground between full-fledged democracy and outright dictatorship is actually the most common political condition today of countries in the developing world and the post-communist

28. Guillermo O'Donnell \& Paul Schmitter, Transitions from Authoritarian Rule: Tentative Conclusions about Uncertain Democracies (Johns Hopkins University Press, 1986). See Juan Linz \& Alfred Stepan, Problems of Democratic Transition and Consolidation: Southern Europe, South America, and Post-Communist Europe (Johns Hopkins University Press, 1996) (discussing an authoritarian-democratic hybrid category to capture the deep state structures that remain in many of the affected countries despite the popular uprisings demanding change). See also A. Stepan \& J. Linz, Democratization Theory and the 'Arab Spring,' 24 J. of DEMOCRACY 2, 15-30 (2013).

29. D. Korten, Third Generation NGO Strategies: A Key to People-Centered Development, 15 World Development, Supplement 1, 145-59 (1987). See also M. Bratton, The Politics of Government-NGO Relations in Africa, 17 World DeVElopment 4, 569-87 (1989). 
world. ${ }^{30}$

While NGOs remain crucial to promote civil society, consolidate democracy, and build social capital, the fruitful application of advocacy policies employed by activists to achieve these objectives depend on contextual factors such as the politics of power within institutions and the extent to which grassroots organizations are able to carry out their tasks unrestricted. ${ }^{31}$

NGOs nevertheless remain significant facilitators of transition periods, serving as "microorganisms of the democratic process." ${ }^{32}$ In fact, the more NGOs that enter into the political and institutional landscape, the more opportunities for networking and creating coalitions of civic actors to place pressure on the state to adhere to materializing democratic principles. ${ }^{33}$ NGOs thus "enhance democracy by expanding the number and range of voices addressing government." ${ }^{34}$ In the same vein, studies on social movement theory have broadly addressed the process of mobilizing participants for broad, sustainable movements. ${ }^{35}$ While political culture and structure are key reference points for analyzing these multi-stage processes, enclosing activities are particularly helpful to comprehend the nexus between political participation and social protest in Egypt. ${ }^{36}$ In the second half of the $20^{\text {th }}$ century, the epistemological approach to framing in the social sciences emerged. ${ }^{37}$ Numerous social movement specialists

30. See T. Carothers, The 'Sequencing' Fallacy, 18 J. of Democracy 1, 17-18 (2007).

31. See, e.g., Terje Tvedt, Angels of Mercy or Development Diplomats? NGOs And Foreign AID (James Currey ed., Trenton, Africa World Press) (Oxford 1998).

32. Sidney G. Silliman \& Lela Garner Noble, Citizen Movements and Philippine Democracy, Organizing for Democracy: NGOs, Civil Society, and the Philippine State (1998), at 306.

33. Bratton, supra note 29. (citing Joel Beinin's argument that it wasn't the work of Egyptian NGOs that mobilized the masses on Tahrir Square, but that the uprisings "grew out of diverse social protest movements over the previous decades involving urban intelligentsias, disaffected educated youth, blue-and white-collar workers and professionals, and marginalized religious communities and regions." Painting a bleak picture of NGOs' ability to mobilize individuals to form a powerful movement, theorizing about the link between mobilization, participation and democracy, and noting that it is important and understudied). See J. Beinin, Civil Society, NGOs, and Egypt's 2011 Popular Uprising, 113 South Atlantic Quarterly 2, 306 (2014). See also Carew Boulding, NGOs, Political Protest, and Civil Society, Chapter 2 (Cambridge University Press, 2014).

34. Silliman et al., supra note 32 (discussing that the heralded success stories of NGO activity, especially in developing countries, has fueled more critical approaches that emphasize the necessity to embrace the complexity of the processes).

35. Steven M. Buechler, Beyond Resource Mobilization? Emerging Trends in Social Movement Theory, 34 Sociological Quarterly 2 (1993).

36. J. Goodwin \& J. Jasper, Caught in a Winding, Snarling Vine: The Structural Bias of Political Process Theory, 14 Sociological Forum 27-54 (1999).

37. Atef Said, Three Lessons for Social Movement Research From the Egyptian Revolution, MoBILIZING IDEAS, Mar.1., https://mobilizingideas.wordpress.com/2017/03/01/three-lessons-forsocial-movement-research-from-the-egyptian-revolution/ ("As sociologists of revolutions and 
adapted Erving Goffman's sociological work from the mid-1970s and applied the rudimentary conceptual notions of it to cases of mass protest mobilization in their field. ${ }^{38}$ When Goffman conceptualized the phenomenon, he used an interactionist perception to exemplify that frames are perpetually and concurrently constructed and reconstructed..$^{39}$ Some scholars have inspected the uprisings in Egypt and employed these analytical structures to analyze the role of social media, notably Twitter and the use of specific hashtags to track conversations and updates on different events and topics on that platform. ${ }^{40}$

While it is essential to understand the socio-legal developments with regards to NGO laws in Egypt from a historical perspective, it is also important to examine different frames and actors, such as the reemergence of a terrorist

mobilizations, we should reject a techno-deterministic account that studies social media in a social vacuum. And if we are to do justice to the complexities of the story, we should also reject ahistorical accounts of social media that see it as stagnant. Obviously, social media played a different role with respect to mobilizing the various Arab spring countries. The real question is not whether or not social media was a (or the) decisive factor in the Arab spring, but in what ways online activism intersected with offline activism, as well as why the interaction between the two changed from time to time, within the same context. Rather than merely analyze the advantages and limitations of social media use, we should focus on the dynamics and processes of how social media intersects with mobilization, and the temporal shifts of this intersection. Activists used social media for a number of purposes: to plan mobilization, to create frames, and to share tips about protests, among other things. But social media's intersection with mobilization shifted in Egypt during the uprising. This shifting role went through at least three distinct stages").

38. See generally Erving Goffman, The Presentation of Self in Everyday Life (Garden City, NY: 1959).

39. Francesca Polletta \& M. Kai Ho, Frames and Their Consequences, The Oxford Handbook of Contextual Political Analysis, 187-209 (2006) (Robert E. Goodin \& Charles Tilly ed., Oxford Handbooks Online 2008). (introducing frame and counter-frame analysis to the study of social movements and counter-movements. In this respect, David Snow highlighted the significance of using frames in order to launch meaning for collective action and social movement organizations (SMOs). He argued that this process, comprises multiple perceptions of issues that fuel various concepts and that have to be consolidated, which they call "frame alignment." $\mathrm{He}$ refers to it as:

The linkage of individual and SMO interpretive orientations, such that some set of individual interests, values and beliefs and SMO activities, goals, and ideology are congruent and complementary. [...] By rendering events or occurrences meaningful, frames function to organize experience and guide action, whether individual or collective. So conceptualized, it follows that frame alignment is a necessary condition for movement participation, whatever its nature or intensity).

See also David Snow et al., Frame Alignment Processes, Micromobilization, and Movement Participation, 1986 American Sociological ReV. 464.

40. The findings showed that keywords used online had a vital impact on disseminating knowledge across the web among a network of well-connected activists. While this work discloses the gatekeeping function of bloggers and cyber activists in the process, it reveals little about the state's intention and role to create meaning. 
discourse in relation to national security at the domestic level with the rise of the Islamic State of Iraq and Syria ("ISIS") in the past few years. ${ }^{41}$

In the future, a well-organized coalition of NGOs could make continuous, meaningful impacts on public discourse and policy guidance, and provide the direction that Egyptian civil society currently needs. Soon after taking office on June 8, 2014, the Egyptian President 'Abdel Fattah el-Sisi called on NGOs in Egypt to register under the new Law No. 71 of $2017 .{ }^{42}$ Interesting, this law was the first legislation passed under former President Mubarak; however, it remained unenforced for several years due to extensive opposition, political dissent, and confrontation. ${ }^{43}$ Egypt's Ministry of Social Solidarity has since released a new NGO law to replace the law No. 84 of 2002, which again called upon all national and international NGOs to officially register their organizations with the ministry. ${ }^{44}$ Human right defenders and political activists see this move as a way to subject NGOs' activities to additional government oversight. ${ }^{45}$

41. Owen Gleiberman, Tribeca Film Review: 'Hell on Earth: The Fall of Syria and the Rise of ISIS, VARIETY, Apr. 30, 2017, http://variety.com/2017/film/reviews/hell-on-earth-the-rise-of-isisreview-1202404275/ ("The radical terror army known as ISIS operates far less in the shadows than the underground rebels of Al-Qaeda. Yet for most Westerners, the image of the Islamic State remains that of an abstract and rather murky cult of hooligan warriors").

42. Ahmed Gomaa, Egypt's New NGO Law Will Further Shackle Civil Society, ALMonitor, June 11, 2017, http:/www.al-monitor.com/pulse/en/originals/2017/06/egypt-ngo-lawratified-sisi-crippling-restrictions-freedom.html ("Foreign bodies also slammed the new law. In a May 31 statement, the European External Action Service said, "The new NGO law in Egypt is bound to put an additional burden on NGOs' activities and restrict the space of debate and discussion in the country. It risks making civil society's contribution to political, economic and social development more difficult." The statement added that some provisions of this law are "likely to directly affect European cooperation assistance to Egypt," since "a large part of our cooperation relies on NGOs as important implementing partners."On June 1, Germany's Federal Government Human Rights Commissioner Barbel Kofler expressed her concern about the law in a statement, saying, "It severely restricts rights and freedoms of civil society organizations").

43. N. Abdalla, Civil Society in Egypt: A Catalyst for Democratization? 10 INT'L. J. OF NotFOR-PROFIT LAW 4 (2008), http://www.icnl.org/research/journal/vol10iss4/special_2.htm [https://perma.cc/6S3C-ZY8T] (last visited Sep. 4, 2016) ("Over the past decade, it has been noted that the West (mainly Europe and the United States) tends to view civil society as a catalyst or engine for democratization, especially in the Arab world. The role played by civil society in some countries of Eastern Europe and Latin America leads to a hope that other countries can make a successful transition to democracy even if they are still confronting some problems of democracy consolidation. Undoubtedly, this trend also reflects the West's will to find a reliable partner, capable of achieving a transition to democracy in a region that is characterized, on the one hand, by authoritarian Arab governments reluctant to implement significant reforms, and, on the other hand, by a secular opposition unable to counterbalance the power").

44. Gomaa, supra note 42.

45. Mariam Risk, Egypt's NGOs Continue Struggle with Restrictive Draft Law, AHARMONLINE (Sept. 22, 2014 ), http://english.ahram.org.eg/ NewsContent/1/64/111294/Egypt/Politics-/Egypts-NGOs-continue-struggle-with-restrictive- 
One of the main arguments in support of the new law is that it both preserves the old limitations on NGO actions and introduces new restraints, including a governmental "coordination committee" to control civil society organizations" access to funding, specifically the international funding and aids. ${ }^{46}$ In theory, the new legislation allows the government to shut down any NGO at will under national security claims ${ }^{47}$ It also allows the government to restrict funding, freeze assets, confiscate property, and deny requests to affiliate with international bodies. ${ }^{48}$ In essence, these new restrictions would make it difficult for registered NGOs to remain independent from the government. It should be noted that independent NGO activity enhances and encourages civil society, democracy, good governance, and social capital. ${ }^{49}$ Traditionally, NGOs were seen as important for economic support; however more recent literature from the academic, donor, and NGO communities alike argues that the contribution of

dra.aspx [https://perma.cc/4DA8-ZNRS] (last retrieved Sep. 4, 2016) ("Civil groups in Egypt say that a new draft law governing NGOs is unconstitutional and designed to hamper groups that serve as watchdogs or spark criticism....Egypt's NGOs say they are facing uncertainty after the government announced they will have to officially register under a law from the era of toppled autocrat Hosni Mubarak, part of what they say are continual efforts to eliminate certain civil groups that might be seen as posing a threat. The social solidarity ministry announced...that all civil groups must be registered with the government, as per law 84 issued in 2002, which critics say was used to hamper rights organizations' mobility and freedom under Mubarak's regime").

46. Id. ("The government says the law aims to ensure transparency in NGOs' funding and activities so they're not used as a front for illegal conduct. In an interview... Social Solidarity Minister Ghada Wali said she preferred the law to be passed after a parliament is elected "because there's a lot of uproar and disagreements" surrounding it. "We cannot deny this country is subject to foreign interference and NGOs are fertile land for that ...”).

47. Ahmed Aboulenein, Egypt Issues NGO Law, Cracking Down on Dissent, ReuTERS, May 29, 2017, http:/www.reuters.com/article/us-egypt-rights/egypt-issues-ngo-law-cracking-down-ondissent-idUSKBN18P1OL ("Egypt issued a new law . . . that regulates the work of nongovernmental organizations, a measure seen by rights groups as the latest sign of a growing crackdown on dissent against President Abdel Fattah al-Sisi. Human rights groups and activists say the law in effect bans their work and makes it harder for charities to operate. The measure restricts NGO activity to developmental and social work and introduces jail terms of up to five years for non-compliance. It gives Egypt's 46,000 NGOs one year to comply or face being dissolved by a court").

48. Elisabeth Lehmann, Restrictions on Egyptian NGOs: Silencing the Voice of Civil Society, QANTARA.DE (Dec. 29, 2014), http://en.qantara.de/content/restrictions-on-egyptian-ngos-silencingthe-voice-of-civil-society ("In recent months, Egyptian President Abdul Fattah al-Sisi has passed a number of laws that will weaken the country's civil society. Local NGOs and foreign foundations alike will suffer under the new law....The obligation to register is part of a campaign against Egyptian civil society. In the past few months, President . . . al-Sisi has signed into law a number of bills that exert pressure on civil society. Among others, criminal law has been made stricter. According to the new legislation, organizations can in future be prosecuted for receiving funds from abroad if such funding undermines the interests of the Egyptian state").

49. See generally Tvedt, supra note 31 . 
NGOs to development might be more important for political rather than economic reasons. ${ }^{50}$ They are seen as significant bolsterers of civil society by virtue of their participatory, inclusionary, and democratic approach. ${ }^{51}$ In fact, NGOs bolster democracy in three primary arenas:

\section{A. Strengthening Liberal Democracy}

As autonomous actors, NGOs have the power to alter the institutional arena. By including more actors in historically closed spaces, opportunities increase for a wider range of interest groups to emerge and have a voice in the institutional arena. ${ }^{52}$ Consequently, more independent and autonomous organizations have the ability to "check" the activity of state institutions and to act as a "watchdog.",53 The more NGOs that enter into the fields, the more opportunities emerge for networking and creating coalitions of civic actors to place pressure on the state to adhere to democratic principles. ${ }^{54}$ NGOs have become the most important facilitators of civil society in Brazil, where NGOs have been successful in promoting democracy. ${ }^{55}$ Likewise, rapid growth and imperative political roles

50. Aboulenein, supra note 47.

51. See Michael Bratton, The Politics of Government-NGO Relations in Africa, 17 WorLD DEVELOPMENT 569 (1989) (explaining the growth of NGOs in Africa and proposing a framework for analyzing the dynamics of government-NGO relations in various African nations, the strategies used by governments to exercise control, and by NGOs to assert autonomy) ("Non-governmental organizations (NGOs), deservedly or not, have gained a reputation as the leading practitioners of rural development in Africa. African governments have responded ambiguously to the presence of these new agencies, on the one hand valuing the economic resources NGOs can raise, but resisting the political pluralization implied by popular development action....An argument is made that politics, rather than economics, best explain the contribution of NGOs to development, as well as the attitude of governments toward the burgeoning voluntary sector").

52. Gustavo Capdevila, Civil Society Has Something to Say, Global Policy Forum (Oct. 27, 2008), https:/www.globalpolicy.org/component/content/article/177/31594.html ("The responsibility of striving for solutions lies with governments 'because the market forces have demonstrated that they cannot solve the issues,' . . . 'But governments do not have sufficient strength on their own, and must take into account 'the thinking of their own people as translated by civil society movements").

53. See John Garrison, From Confrontation to Collaboration: Civil SOCIETY-GOVERnMENT-WORld BANK RELATIONS IN BRAZIL 10 (World Bank 2000), http://siteresources.worldbank.org/CSO/Resources/GarrisonBrazilCStudy.pdf (providing a brief overview of the civil society sector with emphasis on NGOs, analyzing the advances made in relations among the civil society, explaining the advantages of promoting closer collaboration among NGOs and various sectors, and describing some of the necessary steps to further improve these relations).

54. Bratton, supra note 29.

55. G. Sidney Silliman \& Lela Garner Noble, Citizen Movements and Philippine Democracy in Organizing for Democracy: NGOs, Civil Society, And the Philippine State 280, 306 (G. Sidney Silliman \& Lela Garner Noble eds. 1998). 
played by NGOs have amounted to an "associational revolution" as an economic boycott in Cambodia, Indonesia, the Philippines, and Thailand, where NGOs "improve democracy by increasing the number and variety of powers and voices representing the government." 56

In the context of ongoing transition, an opening of civic space and funding options for NGOs in a place like Egypt gives incentives and opportunities for Egyptian nationals living abroad to contribute their perspective, training experience, and specialization to enhance civic life in Egypt. ${ }^{57}$

\section{B. NGOs Sustain Popular (Grassroots) Organizations}

Grassroots organizations ("GROs") are often marginalized organizations that find themselves outside of institutional structures as they tend to represent the poorest and most disenfranchised members of society. ${ }^{58}$ NGOs serve to socially and publicly broaden and strengthen the personal and organizational capacity for citizen participation by advocating and campaigning for GROs' issues in an attempt to affect public policy. ${ }^{59}$ In the same vein, Julie Fisher, a current associate and retired program officer of the Kettering Foundation, argues that this type of "bottom-up democracy" has been instrumental in changing public relations with the institutional structure that it may lead to "top-down political change." ${ }^{\circ 0}$

\section{NGOs Behave as Watchdogs for State: "State-Society Relations"}

NGOs check state power by challenging its autonomy on both national and

56. Id.

57. This effect increases the depth of resources, experience, and perspective to the civic pool, which ultimately can help the effectiveness of Egyptian civic groups who seek to face society's challenges. The initiative would create a bridge, so to speak, and share experiences in civil society, where volunteerism is encouraged from a young age, and the relatively less developed and less encouraged civic sector in Egypt with the aim to promote constructive civic life. For further details on this point, see Abdulwahab Alkebsi, Nathan J Brown, \& Charlotta Sparre, Reconstructing the Middle East: Political and Economic Policy (2017), at 121.

58. Norman Uphoff, Grassroots Organizations and NGOs in Rural Development: Opportunities with Diminishing States and Expanding Markets, 21 World DeVELOPMENT 607 (1993) ("This ... undertakes to deal systematically with nongovernment organizations (NGOs) and grassroots organizations (GROs), usually treated as a residual category. Ten levels for development decision making and action are identified in the tradition of central place theory. Three of these are considered 'local' or 'grassroots' because of their collective action possibilities. Then, three sectors are delineated, instead of the usual two. NGOs are part of the collective action sector which differs from the public and private sectors in theoretically consistent ways").

59. See generally John D. Clark, Democratizing Development: The Role of Voluntary Organizations (1991). See also Anthony J. Bebbington, Hernan Carrasco, Lourdes Peralbo, Galo Ramon, Jorge Trujillo \& Victor Torres, Fragile Lands, Fragile Organizations: Indian Organizations and the Politics of Sustainability in Ecuador, 18 TRANSACTIONS OF THE InSTITUTE of British GeOgraphers New SERIES 179 (1993).

60. Fisher supra note 17, at 126. 
local levels. NGOs played a dynamic role in the third wave of democratic transitions and democratic consolidation (e.g., Latin America, Brazil, and various Arab Spring countries). For instance, in the 1970s, Brazilian NGOs were important players in the groundswell of civil society forces pressing for political amnesty and opening the political floor for reconciliation and integration among several political and opposition groups in the society to participate in public life. ${ }^{61}$

Ultimately, NGOs have contributed to the struggle for democracy in many states and remained essential to their political development and their transition towards democracy. ${ }^{62}$ By serving as watchdogs, NGOs press for changes in state performance and, eventually, in developing an alternative set of perceptions and policies. ${ }^{63}$ In modern political theory, indigenous culture is often viewed as interfering with modern western democratic development; however, NGOs both foster democratic development and help preserve indigenous culture because NGOs have built-in mechanisms for the integration of GROs. ${ }^{64}$

It should be emphasized that civil society organizations are prerequisites in Egyptian democratic and social development due to the positive roles they play in Egypt across multiple sectors, including the rule of law, human rights, education, environment, spirituality, culture, etc. ${ }^{65}$ These various sectors should be broader, but that is to help make the argument that the current laws and practical challenges for civic groups detract so much potential for development

61. Julie Fisher, Nongovernments: NGOs and the Political Development of the THIRD WORLD 126 (1998) (detailing the influence these organizations have had on world political systems and the hope they bring to the possibility for sustainable development within the political development of the Third World).

62. Gerard Clarke, Non-Governmental Organizations (NGOs) and Politics in the Developing World, 40 Political Studies 36 (1998).

63. Id. See also Larry Diamond, Juan J. Linz \& Seymour Martin Lipset, Introduction: What Makes for Democracy? in Politics in Developing Countries: CoMPARING EXPERIENCes with DEMOCRACY (Diamond et al. eds $2^{\text {nd }}$ ed. 1995) (presenting case studies about democracy in Asia, Africa, Latin America, and the Middle East, the factors that facilitate and obstruct the development of democracy around the world).

64. Uphoff, supra note 58 (noting that many NGOs target the most marginalized people in society. For instance, Peace and Plenty Association ("PPA") works to alleviate some of the hardships endured by people living in unplanned communities, from educating children, to bringing electricity and water to homes, to paving roads. These are practical problems that require practical solutions that the government simply can't address in a country with devastatingly high levels of poverty. The restrictions on NGOs have in fact had a negative impact on millions of Egyptians due to state interference with many charities and NGOs that offer food and medical care to the poor).

65. See generally Timo Behr \& Aaretti Siitonen, Building Bridges or Digging Trenches? Civil Society Engagement after the Arab Spring 1-27 (Finnish Inst of Int'1 Aff., Working Paper No. 77, 2013), www.fiia.fi/assets/publications/wp77.pdf [https://perma.cc/K7DM-5DN]. ("The recent wave of uprisings in the Middle East has drawn renewed attention to the important role of civil society and social movements in democratic transition processes. Across the Arab Middle East civil society actors initiated a process of non-violent protests and mass demonstrations that eventually resulted in the toppling of autocratic regimes in Tunisia, Egypt, Libya, and Yemen."). 
and progress in civilian sectors in Egypt. ${ }^{66}$ In the democratic atmosphere that Egypt expects, foreign funding with transparency would create opportunity for Egypt's youth to work and train in an environment conducive to developing capable workers in government administration, social work, law, and other fields. ${ }^{67}$ This initiative would improve government functionally down the line given the overlaps in skill sets between government and civil society and provide Egyptian youth with a reasonable living. ${ }^{68}$ Further, Islamic charities were shut down recently with little international or local media attention, leaving many poor Egyptians without necessary assistance from these charities, whose assets were frozen arbitrarily with little legal justification. ${ }^{69}$ In this respect, an anti-NGO propaganda that has been prevalent in the mass media against human rights organizations and youth groups has to be emphasized to public opinion. ${ }^{70}$

66. See id. Noting that the repressive anti-NGO policies in the post-Morsi era serve as evidence that efforts by Egyptian state institutions to establish trustworthy relations with civil society are at its lowest. The government's discourse and subsequent policies putting words into practice have only deepened the divide between state and society.

67. See Dina Shehata, Youth Activism in Egypt, Arab Reform Brief (2008).

68. Historically, it's kind of like a Mohammad Ali era training bureaucrats in Paris except within Egypt. He was an Ottoman Albanian commander in the Ottoman army, who rose to the rank of Pasha, and became Wāli, and self-declared Khedive of Egypt and Sudan with the Ottomans' temporary approval. Though not a modern nationalist, he is regarded as the founder of modern Egypt because of the dramatic reforms in the military, economic and cultural spheres that he instituted. He also ruled Levantine territories outside Egypt and the dynasty that he established would rule Egypt and Sudan until the military coup of 1952. It should be noted that multinational NGOs or international Egyptian NGOs that finance Egyptians to go abroad for experience and skill set and capacity development and then return to the home country to share experience. See Shadi Hamid Civil Society in the Arab World and the Dilemma of Funding, BrookIngs Inst. (October 21, 2010), http://www.brookings.edu/research/articles/2010/10/middle-east-hamid [https://perma.cc/X7QN-UL3A]. ("Western funding for Arab NGOs has grown markedly since the attacks of 9/11...Many Arab NGOs instituted a policy of not accepting any American government funding in 2004 due to the unpopularity of the Bush administration's policies. Some of them revised policy and began accepting funding in 2009 due to the perceived popularity of President...Obama.").

69. Transparency as a prerequisite for all these groups whether they be on the Islamic or western-backed side of the spectrum should be introduced. Behr \& Siitonen, supra note 69, at 11. ("In the Arab world, religious charities, guilds and educational institutions represent an age-old form of organization that date back many centuries. The principle of charitable giving is a cornerstone of Islam and has enabled the growth of an Islamic charity and relief sector that is based on the traditions of zakat (obligatory charity), sadaqah (voluntary charity), and waqf (public endowment).").

70. Hamid, supra note 68. ("In regards to Egypt, the Obama administration, shortly upon entering office, made a decision to provide bilateral assistance only to organizations registered by the Egyptian government. Of course, such organizations are approved for a reason: they are not at all threatening to regime interests and provide the facade of an active civil society and political openness. As for political groups or movements, they generally have not received US assistance. 
It is important to counter falsehoods in anti-civic media and government rhetoric by providing a legitimate space for those accused in the media or in the government to explain themselves. ${ }^{71}$ Further, there were a few instances of corrupt civil society groups squandering donor funds, which is a key issue that can be brought to light with transparency requirements in the law. ${ }^{72}$ Since Egyptian state media is constantly attempting to manipulate its people into believing that civil society activity is harmful to the country, a real dialogue would be very helpful in discrediting state sponsored anti-NGO publicity. ${ }^{73}$ Human rights activists argue for the necessity of both foreign and local NGOs. They also promote a culture of civic participation and seek to identify where Egypt needs the most civic energy and resources to confront society's challenges. Human rights activists are continually pressing the government for serious dialogue and occasionally partner with civil society so that NGOs and the government can ultimately work toward the same goal: addressing the plight of the Egyptian people. ${ }^{74}$ Assuming Egypt values democracy, which is written in its

Such groups are obviously more controversial as their goals extend well beyond the mandate of NGOs, which are relatively small and focused on more limited objectives").

71. Id. (noting that if properly documented and circulated, this can help change public and government perceptions of the activists for social change).

72. Cobus de Swardt, Corruption in Civil Society Organizations, DisRupt \&InNovative Future Civil Society Organizations, July 14, 2015, https://disrupt-andinnovate.org/corruption-in-civil-society-organisations/ ("Corruption is usually seen as a problem that is pervasive in government and the public sector as well as in finance and business or when both of them interact. However, civil society is arguably no more immune to potential corruption than companies or governments. According to a Transparency International (TI) survey 28 per cent of people globally think that civil society organizations (CSOs) are corrupt or extremely corrupt. In some countries, such as Lebanon, Serbia, Sudan, Venezuela, the percentage is even above fifty"). See also Nourhan Dakroury, Convictions in NGO Trial 'a Disgrace': Guilty Verdicts and Prison Sentences in NGO Trial Draw International Condemnation, DAILy News EgYPT (June 4, 2013), http://www.dailynewsegypt.com/2013/06/04/convictions-in-ngo-trial-a-disgrace/ [https://perma.cc/9JF4-ZMLW]. (“[D]escribing the trial as a 'government-led witch-hunt intended to strangle civil society activity and limit free expression in post-revolutionary Egypt'... The convictions hinged on the fact the NGOs were unlicensed, making their offices in Egypt illegal . ..”) (highlighting the fact that a genuine discussion concerning NGO benefits, roles, and rights in Egypt has never really been had in any credible way).

73. Behr \& Siitonen, supra note 65, at 14-15. ("The Arab Spring revolutions provided a sudden boost to civil society activism across the Middle East. Decades of tight state controls and repressions were wiped away or stopped being reinforced, while civil society activists, no longer fearful of state repression, clamored for a new role in political and social life. In Egypt, home to a comparatively robust civil society prior to the revolution, CSOs were able to thrive in the immediate aftermath . . . creating concerns that civil society will remain tightly controlled by the state").

74. This would allow for a masse social action that was seen during the uprising to be channeled to affect the people directly in a wave of productive social good [...] ultimately aiming to win back the people's sympathies or the revolt and the mindset of non-complacent, active, 
Constitution, it must address the restrictions on civil society and strengthening its ties with foreign civil society. ${ }^{75}$

Moreover, given the relative unrest in the Middle East, including the phenomenon of violent "jihad" and militancy in places like Libya and the Sham (Syria) - and even some of the misguided chaos on the streets in Egypt, reformminded, public service in civil society is the moderate, civilized alternative. ${ }^{76}$ It is vital to stress that NGOs do not just function as a reactionary measure to human rights or civil liberties violations, as the government does not have the capacity to meet the needs of all of Egypt's vulnerable population. ${ }^{77}$ By the same token, the value cultural exchange, especially between the Middle East and the West, is indispensable as there are several NGOs that offer free foreign language studies and cultural interactions between Egyptians and foreign nationals. ${ }^{78}$ By doing so, NGOs create an atmosphere of trust and friendship in a Muslim majority country that tends to mistrust the West. ${ }^{79}$ Additionally, Egypt's economic development

constructive change that it brought about. Egypt: See NGO law threatens to annihilate human rights groups, AMnesty International, May 30, $201 \mathrm{https} / /$ www.amnesty.org/ en/latest/news/2017/05/egypt-ngo-law-threatens-to-annihilate-human-rights-groups/ (“"“This is a catastrophic blow for human rights groups working in Egypt. The severity of the restrictions imposed by this law threatens to annihilate NGOs in the country, at a time when the authorities' escalating crackdown on dissent makes their work more important than ever ...").

75. Behr \& Siitonen, supra note 65 , at 17. ("A second challenge concerns the emerging character of state-civil society relations. By setting the legal-political framework in which civil society evolves, the state controls the enabling environment for civil society"). "The Arab Republic of Egypt is a sovereign state, united and indivisible, where nothing is dispensable, and its system is democratic republic based on citizenship and the rule of law." See CONSTITUTION OF THE ARAB RePublic OF EGYPT Jan. 18, 2014, Art. 1 (Egypt), http://www.sis.gov.eg/Newvr/Dustor-en001.pdf.

76. Human rights scholars argued that opportunities to do good, be it for the sake of secular, progressive values, Islamic values of mercy, service, justice, some other practical or altruistic reason, or a combination of them all, that also provides an opportunity to make a normal life. The initiative can also help with unemployment, especially amongst youth in Egypt, while teaching people valuable lessons about civic life, which can help prospects for regional stability, or further training that helps develop skills for future employment lessens the chances of people doing something non-constructive or violent because one lacks opportunity. Aboulenein, supra note 47.

77. For instance, Egypt has had a surge of refugees pouring in from Africa and the Middle East. The state simply doesn't have the funds to support them. Without the help of NGOs, these refugees would be homeless and would not have access to education or medical care. Gomaa, supra note 42 .

78. Shadi Hamid, Civil Society in the Arab World and the Dilemma of Funding, BrookIngs, Oct. 21, 2010, https://www.brookings.edu/articles/civil-society-in-the-arab-world-and-the-dilemmaof-funding/ ("Civil society played a critical role in democratic transitions in Eastern Europe and Latin America. To the disappointment of many, it hasn't played that role in the Arab world. Across the region, non-governmental organizations have been weakened and tamed. Meanwhile, the United States, the EU, and the international community continue to emphasize the importance of civil society development").

79. Id. A good example is the Cairo Institute for Human rights ("CIHR"), which has created 
has benefited significantly from the help of NGOs, as Egypt has had a difficult time revitalizing its middle class after the revolution. ${ }^{80}$ Small and medium businesses are failing due to massive corruption, huge financial fraud by parasite capitalism, misappropriation of public funds, lack of resources and suitable startup funds, which numerous NGOs have been working to combat by offering technical expertise, financial aid, and consulting to small business owners. ${ }^{81}$

\section{PART THREe: THE LEGAL Status QUO OF NGOS, CIVIL SOCIETY, AND POLITICAL ACTIVISM: ANY REFORM? AND THE WAY FORWARD}

\section{NGOS' STATUS QUO IN EGYPTIAN LAW AFTER EGYPT'S UPRISINGS: LATEST DEVELOPMENTS AND A WAY FORWARD}

By putting an end to repressive policies, as recommended by this Article, a productive wave of civic engagement could be activated that could help fuel much required social change. ${ }^{82}$ The lack of trust between the Egyptian state and its public is the consequence of endless state repression and political violence exerted by government security forces and the military in the years prior and following the fall of the Mubarak rule. Regaining the trust and support from those who suffered most is fundamental to reach the goal of a peaceful transition. ${ }^{83}$ The ultimate goal would consist of winning back the people's sympathies for the revolt and the mindset of non-complacent, active, constructive change that it brought about. Allowing several actors across national boundaries to cooperate would also strengthen transnational ties - and foster a transfer of resources and knowledge - between foreign and Egyptian civil society. ${ }^{84}$

\section{i. CONSTITUTIONAL, LEGAL FRAMEWORK, AND REGULATORY ELEMENTS}

Following the Egyptian revolts in 2011 and 2013 by the Egyptian people and the military, which exiled President Mubarak and overthrew President Morsi, respectively, the Egyptian Constitution of 2014 explicitly declared equality among the Egyptian citizens, criminalized discrimination, provided for equal opportunity for all Egyptians, and provided for cultural and social services. In other words:

a cross cultural dialogue on issues such as international human rights.

80. Id.

81. An example is The Small Enterprises and Community Development Association ("SMECDA") which sends field officers to small businesses to offer different services meant to help the business thrive. Mohamed 'Arafa, Corporate Social Responsibility and the Fight Against Corruption: Towards the Concept of CSR in Egypt after the January Revolution in CORPORATE Social Responsibility in Comparative Perspective, Council on International Law AND Politics (2013), at 182-221.

82. See Behr \& Siitonen, supra note 65

83. Id., at 65 .

84. Id. 
All citizens are equal before the Law. They are equal in rights, freedoms and general duties, without discrimination based on religion, belief, sex, origin, race, color, language, disability, social class, political or geographic affiliation or any other reason. Discrimination and incitement of hatred is a crime punished by Law. The State shall take necessary measures for eliminating all forms of discrimination, and the Law shall regulate creating an independent commission for this purpose. ${ }^{85}$

With regard to the freedom of association and the formation of organization in civil society, Article 73 of the Egyptian Constitutional Charter guarantees and respects this public and constitutional right and stipulates "the right to form nongovernmental associations and foundations on democratic basis." This constitutional provision reads in full:

All citizens shall have the right to form non-governmental associations and foundations on democratic basis, which shall acquire legal personality upon notification. Such associations and foundations shall have the right to practice their activities freely, and administrative agencies may not interfere in their affairs or dissolve them, or dissolve their boards of directors or boards of trustees save by a court judgment. The establishment or continuation of non-governmental associations and foundations, whose statutes or activities are secretive or conducted in secret or which are of military or quasi-military nature is prohibited as regulated by Law. ${ }^{86}$

The Egyptian Constitutional Charter further states:

Citizens shall have the right to organize public meetings, marches, demonstrations and all forms of peaceful protests, without carrying arms of any kind, by serving a notification as regulated by law. The right to peaceful and private assembly is guaranteed without need for prior notification. Security forces may not attend, monitor or eavesdrop on such meetings.... ${ }^{87}$

Accordingly, the Egyptian Constitutional Charter guarantees the right to form NGOs as long as they organize and practice on a democratic basis. As such, no one can intervene in their affairs or dissolve them or their board of directors, except by judicial decisions based on reasonable legal grounds, such as

85. See Constitution of the Arab Republic of Egypt Jan. 18, 2014, Art. 53 (Egypt), http://www.sis.gov.eg/Newvr/Dustor-en001.pdf.

86. Id., at Art. 75.

87. Id. at Art. 73-74. (Additionally, "All citizens shall have the right to form political parties by notification as regulated by Law. No political activity may be practiced and no political parties may be formed on the basis of religion or discrimination based on sex, or origin, or on sectarian basis or geographic location. No activity that is hostile to democratic principles, secretive, or of military or quasi-military nature may be practiced. Political parties may not be dissolved except by virtue of a court judgment"). 
transparency, integrity, exact national security values, preserving public order purposes or other legal principles. ${ }^{88}$

By the same token, the Egyptian Constitutional Charter also allows the formation of syndicates and coalitions on a democratic basis. ${ }^{89}$ The Egyptian Constitutional Charter considers this a fundamental right that allows these groups to attain legal personality, to practice their activities spontaneously, to assure their independence and impartiality, and to defend their rights and interests. ${ }^{90}$ National laws guarantee NGOs' independence and specify their resources and the manner of recording their members and holding them accountable for their conduct in practicing their professional activities according to the codes of ethics and professional/moral conduct. ${ }^{91}$

On the other hand, it should be noted that the most significant legislative framework, besides the Egyptian Constitutional Charter on the formation of NGOs and civil society groups, was issued by the Ministry of Social Affairs (Solidarity) and other official solidarity agencies and is, as follows:

(a) The General Civil Code (Law No. 131 of 1948 as amended);

88. Alyaa Hamed, Civil Society at a Crossroads: Hopes for NGO Regulations that Meet International Standards Have Been Stymied Since the January 2011 Revolution, AL-AHrAm WeEKLy Online, Oct. 16, 2014, http://weekly.ahram.org.eg/News/7482/32/Civil-society-at-acrossroads.aspx (last visited Sep. 4, 2016) ("Recent years have seen a deal of conflict over civil society, with activists and lawyers digging in for a prolonged confrontation with a government, or succession of governments, apparently hell bent on trimming the scale, freedom and financing of non-governmental organisations of various types in Egypt. Since the 25 January Revolution, NGOs claim, the government has come up with draft laws that have often failed to meet international standards for civil society work. More specifically, many of these proposals have run in the face of the Egyptian constitution itself, which recognises and encourages the role of NGOs in public life").

89. "Citizens have the right to form non-governmental organizations and institutions on a democratic basis, which shall acquire legal personality upon notification. They shall be allowed to engage in activities freely. Administrative agencies shall not interfere in the affairs of such organizations, dissolve them, their board of directors, or their board of trustees except by a judicial ruling. The establishment or continuation of non-governmental organizations and institutions whose structure and activities are operated and conducted in secret, or which possess a military or quasimilitary character are forbidden, as regulated by law." EGYPT CONSTITUTION, supra note 85, at Art. 75.

90. Egypt Constitution, supra note 85, at Art. 76. ("The State shall guarantee the independence of all syndicates and federations and their boards of directors may only be dissolved by a court judgment. No syndicate or federation may be established in the military or police agencies").

91. Id. at Art. 77 ("No profession may have more than one syndicate for the regulation of its affairs. Receivership may not be imposed on any syndicate. Administrative bodies may not interfere in the affairs thereof. The board of directors of any syndicate may not be dissolved save by a court judgment. The opinion of the syndicate shall be sought on draft legislations pertaining to it"). 
(b) Commercial Registry Law (No. 34 of 1976 as amended by Law No. 98 of 1996);

(c) Law on Associations and Foundations No. 71 of 2017;

(d) Law No. 107 on the Right to Public Meetings, Processions, and Peaceful Demonstrations of 2013, and

(e) Assembly Law No. 107 of 1914 (which is still enforced and may include additional penal sanctions $).{ }^{92}$

Additionally, there are some universal and regional agreements to which Egypt committed that touch on this topic, including: the International Convention on the Elimination of All Forms of Racial Discrimination ("ICERD"), the International Convention on the Protection of the Rights of All Migrant Workers and Members of their Families ("ICRMW"), the Arab Charter on Human Rights ("ACHR"), and the African Charter on Human and Peoples' Rights ("ACHPR"). ${ }^{93}$

The Egyptian Law on Associations empowers the government to interfere with the registration, governance, and operation of NGOs and encumbers the right of Egyptians to form and operate independent associations. ${ }^{94}$ The new law stipulates that registration is mandatory and binding and that informal, unregistered NGOs are prohibited, yet the grounds for denying registration are overly equivocal, inviting the exercise of excessive government discretion. ${ }^{95}$ The law proscribes NGO's involvement in some "political activities," which has been used to confine NGOs' advocacy or speech along with some penal defamation acts that have been used to silence critics of the government or its senior officials. $^{96}$

92. See Presidential Decree, The Arab Republic of Egypt Law No.107 for 2013 For Organizing the Right to Peaceful Public Meetings, Processions, and Protests, http://www.constitutionnet.org/files/protest_law_issued_nov_24.pdf.

93. See generally International Convention on the Elimination of All Forms of RACIAL DISCRIMINATION (adopted and opened for signature and ratification by General Assembly resolution $2106(X X)$, Dec. 21, 1965 entry into force Jan. 4 1969, in accordance with Article 19, http://www.ohchr.org/EN/ProfessionalInterest/Pages/CERD.aspx; InTERnATIOnAL CONVEnTION ON THE Protection of the Rights of All Migrant Workers AND MEMBERs OF THEIR FAMiLies (adopted by General Assembly resolution 45/158 of Dec. 18, 1990, http://www2.ohchr.org/english/bodies/cmw/cmw.htm; LEAGUE OF ARAB STATES, ARAB CHARTER ON HUMAN Rights, Sep. 15, 1994, http://www.refworld.org/docid/3ae6b38540.html. See generally African Charter on Human and Peoples' Rights (adopted June 27, 1981, OAU Doc. CAB/LEG/67/3 rev. 5, 21 I.L.M. 58 (1982), entered into force 21 Oct.21, 1986), http://www.achpr.org/instruments/achpr/.

94. Hamed, supra note 85 .

95. 'Arafa, supra note 27 , at 170-71.

96. Id. at 172. ("In applying a limitation, a government should use no more preventive means than is completely necessary and may legally entail the formation to be notified of an association. On the other hand, if the government requires persons who wish to create an association to get permission before functioning, it must specify criteria that are obvious, unbiased, and appealable"). 
Moreover, the current new law, through its impermissibly broad sections, gives the Minister of Social Solidarity authority to scatter groups and order the custody of NGO members for otherwise legitimate actions, including: (a) acceptance of foreign resources or funds; (b) correlating with foreign foundations without permission; (c) directing political or trade union actions; and (d) violating "public order or moral standards." ${ }^{97}$ Under this legislation, "all non-profit groups of ten members or more working in social development activities must register with the Ministry of Social Solidarity or face criminal penalties, including up to one year's imprisonment...."98 Theoretically speaking, this present law allows NGOs to work in numerous fields; yet, the scope of permitted NGO endeavors is still constricted and NGOs must have permission from the Solidarity Ministry before working in multiple fields. ${ }^{99}$ The law forbids groups from engaging in any objectives that will be considered as "threatening national unity" or "violating public order or morals,"-imprecise concepts that allow possible oppression. ${ }^{100}$

Recently, the new law to govern NGOs' operations would give the government and security agencies veto power over all activities of Egyptian associations and would doom their independence and neutrality, which these groups have struggled to maintain. ${ }^{101}$ In terms of enacting a new NGO law, the government must promote Egyptians' right to freedom of association as enshrined in the constitution, international law, and human rights laws, of which these groups have struggled for decades to ensure their independence and neutrality.

97. Id., Law No. 70 of 2017.

98. Id.

99. Al-BORA'I, supra note 17. See, e.g., Law No. 10 of 1914 (On Public Gatherings), AlJarida Al-Rasmiyya [Official GAZETTE], June 4, 1923 (Egypt) (on file with author); Law No. 14 of 1923 (Determining the Rules Related to Public Meetings and Demonstrations on Public Roads), Al-Jarida Al-Rasmiyya, [Official Gazette], June 4, 1923 (Egypt).

100. Amy Hawthorne and Mohamed Elgohari, The Ongoing Struggle for Egyptian Civil Society, ATlantic CouncIL, Dec.17, 2013, http://www.atlanticcouncil.org/blogs/egyptsource/theongoing-struggle-for-egyptian-civil-society (last visited Sep. 4, 2016) ("While most attention is on Egypt's constitution ..., the government may be moving ahead with a new NGO law. Minister of Social Solidarity ... announced ... to submit the law, prepared with civil society input...following a "technical review." How the law eventually turns out, particularly with regard to the activities and funding of human rights and democracy NGOs, will be another test under the military-backed government. These groups are both the main advocates of civil society freedoms and the NGOs most vulnerable to a crackdown. With Egypt's security establishment resurgent, its human rights community divided, and much of the public seemingly tolerant of repression, Egyptian civil society will continue to face an uphill battle").

101. Leila Fadel, Egypt Revives Law Allowing Government To Control NGOs, NATIONAL Public RADiO, Sep. 10, 2014, http://www.npr.org/2014/09/10/347468308/egypt-revives-lawallowing-government-to-control-ngos (last retrieved Sep. 4, 2016) ("Egypt's Ministry of Social Solidarity is threatening to prosecute nongovernmental organizations that are not compliant with an oppressive law that allows the government to fully control them. Although it was put on the books in 2002 it was never implemented and human rights groups got around it by registering as private companies. Now they may face prosecution and some NGOs are suspending operations"). 
These groups have fought to maintain these in order to attain democracy. ${ }^{102}$ The new norms introduced by the law would empower the security institutions to disband or dissolve existing groups, pending a court order, or decline to license new groups if it decided their undertakings could "threaten national unity."103 Also, it would allow officials to examine the premises of any association alleged of engaging in the work of a NGO and would enforce crippling restrictions on foreign funding of Egyptian NGOs and their capacity to connect or collaborate with groups abroad. ${ }^{104}$ In addition, the new law would require international organizations to attain permission in advance from an Egyptian governmental commission encompassing Interior Ministry and intelligence service representatives before engaging in any activity in Egypt and the committee may rescind that permission on a discretionary basis at any time and for any reason. ${ }^{105}$

Under the law's provisos, "[a]11 entities that the government considers to be working as nongovernmental organizations would have to apply for reregistration as associations..." and if they fail to do so, they could face the annulment and revocation of their licenses to activate and the seizure of their assets. ${ }^{106}$ The current enacted law would proscribe all associations from engaging

102. 'Arafa, supra note 27, at 172.

103. See generally Sahar Aziz and Hany Thabet, New Draft NGO Law Squeezes Civil Society, DAILY News EGYPT, June 25, 2013, http://www.dailynewsegypt.com/2013/06/25/new-draft-ngolaw-squeezes-civil-society/ (last visited Sep. 4, 2016) ("The executive's latest draft governing nongovernmental organizations ("NGO Law") is a harbinger of what is to come - a brand of social reform that suppresses independence and plurality in civil society not much different than that state of affairs under Egypt's deposed former president. Soon after it was released, Egyptian human rights organizations condemned the draft law on civil work organizations as intrusive as and more draconian than former President Mubarak's NGO law").

104. A number of foreign NGO provisions generate a discriminatory environment, which in result curb foreign civil society support. For example, some articles permit foreign NGOs to join in "licensed" activities, but vaguely and over broadly outlaw their contribution in "partisan" activities that "infringe national sovereignty." See Ahmed Aboulenein, Egypt Issues Controversial NGO Law Cracking Down on Dissent, Reuters, May 30, 2017, http://af.reuters.com/article/africaTech/idAFKBN18Q0L9-OZATP.

105. Aziz \& Thabet, supra note 67 (imposing criminal punishments of imprisonment of at least one year along with a fine of at least EGP 50,000, to EGP 1,000,000 (equivalent to approximately $\$ 55,000$ USD) for infractions. The legal framework for monitoring NGO activity is based on a state discourse that obfuscates the government's intention to control and repress notably human-rights-oriented and pro-democracy organizations that promote civil society. Instead, official explanations create a frame of foreign governments as a construct of otherness and as an object of fear and concern. State sources refer to the importance of protecting national interest and counter manipulative, foreign interference in Egyptian state affairs).

106. Article (4) of the LAW ON Association (NGOs) (providing that the government would have the power to deny the registration of associations [or unions] that did register as NGOs. In this regard, several Egyptian human rights organizations are presently itemized as civil corporations or law firms rather than associations as the de facto Law 84 of 2002, permits the government to deny a group's registration on vague grounds, such as that its work might "threaten national unity or 
in "political activities," a term it defines dubiously, or from undertaking the work of trade unions and groups, which threatens organizations that stimulate labor rights or offer services to workers. ${ }^{107}$ The law further makes engaging in this conduct a punishable criminal offense. ${ }^{108}$ Under the same law, Egyptian associations would not be capable of joining any international association or entity or support or cooperate with one, without government authorization and violations could similarly be punished as a criminal offense. ${ }^{109}$ The current statute would also require the NGOs to report annually to the government and to disclose details of their finances, activities, and internal decision-making. ${ }^{110}$

The extreme regulations of the internal governance of NGOs envisioned by the recent law amounts to government intervention. ${ }^{11}$ In fact, the new law states that "[e]ach group shall have a 'General Assembly' entailing of everyone who has been a member for more than three months and this assembly may call for a meeting based on an invitation from the board or a quarter of the members of the group...." ${ }^{112}$ Further, the applicable law retains requirements from prior laws

national security interests").

107. Aboulenein, supra note 104.

108. Aziz \& Thabet, supra note 79 (noting that regulations of the NGO law provides that banned political activities include "advocating the program of one of the political parties, contributing to electoral campaigns, and putting forth candidates for office." There is a lack of distinction between a political campaign for office and public policy activities, which have to be emphasized).

109. Law No. 70 of 2017, supra note 8, at Art.16.

110. Id. at Art. 23 (describing that the government could order a group to terminate any activity or cancel any decision, and could take the group to court if it failed to comply within 15 days and the associations could appeal these orders to the Administrative Court on non-specified legal reasonable grounds, that draw the group into a protracted, burdensome, and uncertain legal fight with the government authorities).

111. Zeid Ra'ad Al Hussein, UN Right Chief: New Egypt Law Restricts Human Rights, JURIST, June 2, 2017, http:/www.jurist.org/paperchase/2017/06/un-high-commissioner-new-egypt-lawrestricts-human-rights.php ("Egypt's new NGO law [JURIST report] will further restrict human rights advocacy. Law 70, which was passed on May 24, 2017, requires NGO's to be approved by a government agency, for civil society groups to report all information on their funding and activities to the authorities, and to be in compliance with the government's developmental plans. NGO noncompliance with the new measures may lead to closure of the organization for one year, criminal prosecution, five years in prison, and a fine of up to 1 million EGP (around USD 55,000) .. . The new legislation places such tight restrictions on civil society that it effectively hands administration of NGOs to the Government. ... The crucial function of these NGOs - to hold the State accountable for its human rights obligations - has been severely hampered already through asset freezes, travel bans, smear campaigns and prosecutions. This new law further tightens the noose").

112. Law No. 70 of 2017, supra note 8, at Art. 24-41 (citing David Kirkpatrick for the proposition that, "[s]ome advocates said prosecutors might use the law to detain an organization's staff members for many months before a court rules on the charges"). See David D. Kirkpatrick, Human Rights Groups in Egypt Brace for Crackdown Under New Law, The N.Y TIMES, Dec. 26, 
requiring assemblies to pursue the government's approval before raising funds nationally through charity dealings, mailings, or other forms of advertising. ${ }^{113}$ The contemporary law provides, "[t]he organization's activities must accord with the needs of Egyptian society, pursuant to the priorities of development plans..." as interpreted by the committee. ${ }^{114}$ The coordinating committee's approval would also be mandatory before international groups could move money into or out of Egypt or before they could work with any public body. ${ }^{115}$

By the same token, the new law forbids any international organization from functioning in Egypt if it receives any government money, "directly or indirectly," if its activities "infringe on national sovereignty," or if it seeks to distribute "the outlooks or policies of a political party." 116 Additionally, the law requires that "organizations must spend their funds in a way that realizes their purposes and accords with the rules of the activity for which they are licensed in Egypt." $" 17$ The current law gives the government and security agencies discretion

2014, http:/www.nytimes.com/2014/12/27/world/middleeast/human-rights-groups-in-egypt-bracefor-crackdown-under-new-law.html (last retrieved Sep. 4, 2016).

113. Id. at Art.17-18 (noting that, in practice, the Egyptian security services' substantial surveillance of human rights' NGOs working or to address other sensitive issues has dispirited local donors from contributing to such groups, leaving foreign assistances as a dynamic salvation. The law would further restrict this funding from any source outside Egypt, and any international aids would have to be ratified by a coordinating committee entailing of representatives of the State Council (judicial body); the Interior, Foreign Affairs, Justice, International Cooperation, and Social Solidarity Ministries; the Central Bank; and the intelligence service. The law does not specify on what legal grounds the committee could reject to approve funding).

114. Toka Hassan, Egypt's New NGOs Law - More Restrictions \& Harsher Penalties, SHARKAWY \& SARHAN, June 4, 2017, http://www.sharkawylaw.com/egypts-new-ngos-law-morerestrictions-harsher-penalties/ ("Unfortunately, Law 70/2017 issuing the Law for Regulation of Non-Governmental Organizations and Foundations Operating in Civil Society has published on 24 May 2017 (the "New Law"). It provides a more restrictive approach on the way civil society operates in Egypt. It establishes a new quasi-security authority and widens the authority of the government on civil society and puts more restrictions on its operations, resources and activities. Moreover, the Law severely harshens the penalties for violating the Law").

115. Hawthorne \& Elgohari, supra note 76 (noting that all of this can be described as Draconian prison sentences and astronomical fines for conspiring against the Egyptian state therefore fueled fear among civil society with the aim of silencing any subverting activities against the ruling power elite. In this context, the media has been a prime target that was also affected by these measures. The new NGO law provides the legal backing for the government to extend these arbitrary sentences to activists in the non-profit sector along with casting major doubts on the integrity and impartiality of the Egyptian justice system).

116. Hassan, supra note 114. Numerous international NGOs seeking to launch branch offices in Egypt face excessive struggle in doing so, in addition to administrative barriers to operational activity and to international contact.

117. Law No. 70 of 2017, supra note 8 (noting that it is mandatory for international groups working in Egypt to present a semi-annual "achievement report" on any activity for which it is registered. In case of violations, the minister of social solidarity would be able to suspend or 
to stop or confront international civil societies' services at will, in violation of non-nationals' right to freedom of association, which is assured to them in nondiscriminatory rules under the ICCPR. ${ }^{118}$

It should be noted that the contemporary law allows for the formation of associations, NGOs, unions, and non-profit corporations that can be launched under Egyptian civil and corporate laws. ${ }^{119}$ Civil society organizations pursuing "public interest" commitments may be recognized as "NGOs of public benefit" by presidential decree; however, the criteria for determining what the public benefit is are not obviously defined. ${ }^{120}$

In summation, the new Law No. 70 of 2017 comprises several legal barriers to launch an NGO, including:

(a) All associations must be listed [registered] in order to run; informal or unregistered groups are banned; and

(b) Government maintains indefinite and ambiguous grounds for denying registration or access to foreign funds; i.e. subjective and arbitrary government decision-making on matters that "threaten national unity" or run "against public order and public attitude."121

invalidate the permit to engage in that activity by decree, following approval from the coordinating committee).

118. See ICCPR, supra note 15, at Art. 22.

119. According to this law, an association is a "group with a formal structure continuing for a definite or indefinite period and formed by natural or juridical persons, or both together, whose number is not less than ten in all cases, for a purpose other than gaining physical profit" and a foundation or non-governmental institution "is established where a fund is designated for a definite or indefinite period of time, for the realization of a purpose other than profit." See De facto Law No. 84 of 2000, supra note 8, at Art. 1, 56.

120. See De facto Law No. 84 of 2000, supra note 8, at Art. 48, 49, \& 51 (“Any association visualizing the realization of a general interest upon or after its foundation may be vested with the quality of public benefit, by decree of the President of the Republic, upon the request of the association, or of the administrative authority or the General Union for Associations and NonGovernmental Institutions, and the approval of the association in both cases" and noting that "[p]ublic benefit organizations have access to direct government funding").

121. For example:

(i) The association must send a copy of the papers tabled before the General Assembly to the administrative authority at least 15 days before convening the Assembly... and must provide the administrative authority with a copy of the...meeting within 30 days from the meeting. See LAw No. 84 of 2000, supra note 7, at Art. 26.

(ii) The Minister of Social Affairs may appoint acting members of the Board of Directors where there are insufficient members to hold a meeting; and may dissolve this board if the board has not convened a meeting of the General Assembly for two consecutive years. See LAw No. 84 of 2000, supra note 7 , at Art. 40, 42. 
The prevailing law invades upon the assurances provided by international law for free association. ${ }^{122}$ According to international customs, the governmental authorities may restrain the right to freedom of assembly, but "[o]nly on certain narrowly prescribed grounds and only when particular circumstances apply."123 Article 22 of the ICCPR stipulates:

(1) Everyone shall have the right to freedom of association with others ... .

(2) No restrictions may be placed on the exercise of this right other than those which are prescribed by law and which are necessary in a democratic society in the interests of national security or public safety, public order (ordre publique), the protection of public health or morals or the protection of the rights and freedoms of others. ${ }^{124}$

The government may impose limitations only if they are arranged by predominant law and meet the standard of being "necessary in a democratic society" and these "necessary" restrictions must be based on proportionality criterion (emergency circumstances). ${ }^{125}$

Based on the international law commitments, Egypt is obliged to respect and ensure the right to freedom of association, as set out in the ICCPR and the ACHPR. ${ }^{126}$ Egypt may only limit this right through protocols emphasized by law

(iii) Egyptian authorities may prevent NGOs representatives and civil society activists from traveling outside Egypt to contribute in international conferences and meetings and international organization's agents may be prevented from entering Egypt. See LAW No. 84 of 2000, supra note 7, at Art. 42.

122. Hassan, supra note 114.

123. See Human Rights Watch, The Road Ahead: A Human Rights Agenda for Egypt's New PARLIAMEnt 33 (2012), https://perma.cc/DU8F-3NYQ (quoting Prime Minister Essam Sharaf). See also, Heba Afify, Rights Groups Says Egypt Still Needs More Change, EGYPT INDEP. (June 7, 2011), https://perma.cc/Q5X4-GQDV ("In the wake of continuing reports of human rights abuses after the 25 January revolution, the international human rights advocacy organization Human Rights Watch (HRW) is recommending reforms to the Egyptian government . . that they deem essential to ensure a transition to full democracy").

124. See The International Covenant on Civil and Political Rights, supra note 15, at Art. 22. See also, Al-Masry Al-Youm, Solidarity Minister: Government Surveillance of NGOs is Temporary, EGYPT INDEP. (Oct. 15, 2013), https://perma.cc/W7ZN-TRDW ("Social Solidarity Minister . . . said that government monitoring of NGOs would continue as temporary measure to prevent what he described as the 'groups of evil.").

125. 'Arafa, supra note 85, at 172 ("This requires the restraint to respond to a pressing public need and be oriented along the global basic democratic values and ideals."). See also, MANFRED Nowak, U.N. Covenant on Civil and Political Rights: CCPR Commentary 370-79, 394-96 (1993).

126. See African [Banjul] Charter on Human and Peoples' Rights, supra note 15, at Art. 10 
that are essential in a democratic society. ${ }^{127}$ Any restraint should respond to a persistent public need and reflect basic democratic values of pluralism and tolerance. ${ }^{128}$ The proportionality test should be used to define necessary restrictions - i.e. those that are sensibly balanced against the reason for the restraint, and that are not discriminatory on the basis of national origin, political opinion, or belief. ${ }^{129}$ As it stands, the current law does not satisfy Egypt's obligation to protect and safeguard freedom of association, that is highly recommended to ensure transparent, non-discriminatory, swift, and reasonable procedures that conform to international human rights ideals. ${ }^{130}$

In this regard, it should be noted that international donors' and western governments' view that Egyptian government has purposely adopted strategies that endorsed the growth and evolution of a large and dynamic NGO sector, while using coercive power to outline the sector and impact the organizational behavior, as a main reason Egypt's tumultuous transition. ${ }^{131}$ It should be noted that the government is able to support civil society organizations and NGO sector to provide people in need of help and social assistance with vital services for which the state may lack capacity, co-opt organizations into 'voluntarily' acting within the state's interests without any governmental bureaucratic and regulatory procedures, pit various groups in the society against one another, and improve the government's image abroad while questioning liberalism at home. ${ }^{132}$

(stipulating that "(1) Every individual shall have the right to free association provided that he abides by the law. (2) Subject to the obligation of solidarity provided for in Article 29, no one may be compelled to join an association").

127. Al Hussein, supra note 111.

128. Hassan supra note 114.

129. 'Arafa, supra note 27.

130. Id., at 173 (stating some recommendations to Egyptian Parliament, specifically "(6) revise the Press and Media Laws to provide explicitly that journalists will not . . . criminally punished for exercising their rights to freedom of speech, as set out in relevant international law. Also, it is imperative that Parliament specify that the authorities may confine the recording and registration of an NGO only pursuant to the narrowly prescribed terms provided by international law; eliminate all punishments for directing legal NGO actions in unregistered NGOs; and confirm that any involuntary dissolution of an NGO takes place only by judicial order based on severe violation").

131. See generally Sarah Ben Néfissa et al., NGOs AND Governance In the ARAB WorLd (CAiro/New York: Am. Univ. Press, 2005). See also Guilain Denoeux, Promoting Democracy and Governance in the Arab World: Strategic Choices for Donors, NGOs AND GOVERNANCE IN THE ARAB WORLD (2005).

132. Ozlem Altan-Olcaya and Ahmet Icduygub, Mapping Civil Society in the Middle East: The Cases of Egypt, Lebanon, and Turkey, 39 BRITISH J. OF Middle EASTERn StUdies 2, 157-79 (2012) (evaluating the meaning of civil society in Middle Eastern region) ("In recent decades, civil society has become integral to discussions of political liberalization. At the same time, there is a growing rift between international democracy promotion through investment in civil society and the more critical literature on the relationship between the two . . . First, it argues that the boundaries between states and civil societies are indeterminate, making it problematic to expect 
Egyptian civil society is vibrant and strong compared to other Arab countries, as Kareem Elbayar, a legal advisor at Middle East and North Africa region at the International Center for Not-for-Profit Law (ICNL) states: "Despite the highly restrictive nature of its civil society laws, Egypt has one of the largest and most vibrant civil society sectors in the entire developing world." 133 However, the current law differentiates between associations, civil corporations, and NGOs. ${ }^{134}$ These groups are governed by the Solidarity Ministry and are subject to same legal norms, along with non-legal NGOs, including Islamic and Coptic NGOs, the Community Development Association ("CDA"), and advocacy groups. ${ }^{135}$ It is puzzling that Egypt has so much NGO activism, comprising of various human rights devices, given the authoritarian nature of the state for the last sixty years, including routine violations of essential human rights, such as freedom of expression and association (unions), which are indispensable for a robust and healthy civil society. ${ }^{136}$

civil society organizations alone to become catalysts for regime transformation. Second, it shows that expectations of monolithic generation of civic values through civil society organizations do not reflect the actual experience of actors in this realm. Finally, it argues for taking into consideration other sources of mobilization as potential contributors to meaningful political and social transformation").

133. Kareem Elbayar, NGO Laws in Selected Arab States, 7 InT'L. J. Of Not-FOR-Profit LAW 4, 7 (2005) ("Although several other Arab states provide a more liberal environment for the operation of civil society groups, Egypt's influence and status as a trendsetter for the Arab mainstream suggests the particular importance of its civil society sector, laws and practices. As with most Middle Eastern states, licensing of NGOs in Egypt is mandatory. Law 84 / 2002 requires any "group whose purpose includes or that carries out any of the activities of associations and institutions, even if it assumes a legal form other than that of associations and institutions" to operate with a permit from MOSA . . Foreign NGOs are not allowed to operate in Egypt without securing the permission of the Ministry of Foreign Affairs. The Ministry's decision is based on unspecified factors and not subject to any court appeal ...”).

134. See Law No. 70 of 2017 , supra note 8 .

135. Irrespective of these organizations' categorization, most are focused on community development and growth and, besides a few, lack an explicitly political aim,. See James G. McGann, Pushback Against NGOs in Egypt, 10 INT'L. J. OF Not-FOR-Profit LAw 29, 29 (2008) ("In recent years, various political and social indicators have surfaced that highlight a mounting backlash in developing and transitional nations against the rise of civil society as well as the think tanks and other non-governmental organizations (NGOs) that are active within it. As part of a global trend against democratic avenues of participation, increasing state suppression of NGOs has appeared in nations ranging from Belarus to Tunisia. The rising prominence of domestic NGOs and their growing success at engaging the public has increasingly been met with threats from governments that seek to constrain their operations and, in...cases, to orchestrate their collapse").

136. Elbayar supra note 133. Taken in to account various factors influenced that under Mubarak, as non-fair elections, journalists/reporters' prosecutions and trials, and longtime period's implementation of emergency law. Under Morsi's presidency, state's autocracy has continued, for instance, according to the Nadeem Center for Rehabilitation of Victims of Violence ("NCRVV"), there were a lot of cases of police inhumane treatment and torture. 
Historically, from Nasser's rule until Mubarak's, the Egyptian State made some efforts to introduce its civil society to activism and NGOs, but under restrictive laws, including Laws Nos. 348 of 1965, 32 of 1964, and 153 of 1999, which were later laws described as an assassination of civil society that gave the government extensive power over NGOs. ${ }^{137}$ Under the ruling of the al-majlis ala'la lil-quwwat al-musallaha, translated to the Supreme Council of the Armed Forces ("SCAF"), another current enacted law was presented, which duplicated numerous elements of the 84/2002 law and intensified the criminal penalties. ${ }^{138}$ This current existing law has been criticized and characterized under Morsi's rule as a "civil society's nationalization." 139 The succession of laws regulating the NGOs since the 1952 military coup, also known as the Free Officers Revolution, has given the government broad control and significant discretion over NGOs, especially as to funding and governance, which hindered NGOs' legitimate activities. ${ }^{140}$

The Egyptian government showed their willingness to use extralegal force against NGOs, which included transgression of the NGO laws per se, similar to the State Security or the Intelligence and Investigations apparatus' practices before the January uprising, along with periodical attacks, raids, smear campaigns, and prosecutions of NGOs. ${ }^{141}$ The scope of the Egyptian NGO sector

137. McGann, supra note 135, at 31 ("The history of the Egyptian state's repressive control of NGOs shows parallels to obstacles that NGOs have faced in the other countries . . . Democracy activists cite this close relationship as one of the major impediments to building a more equitable and free Egyptian society") (noting, for example, that the government had the power to convene NGO's meetings, transfer their assets to another, and(or) merge/dissolve them). See also Barbara Cochrane Alexander, Law No. 153: Its Impact on Egyptian Nongovernmental Organizations, 7 Human Rights BRief 2, 13-14 (2000).

138. Law No. 70 of 2017 , supra note 8 , at Arts. $87 \& 88$.

139. See generally Srilatha Batliwala and Brown L. David, Transnational Civil Society: AN INTRODUCTION (KuMARIAN PRESS 2006) (pointing out that, there was a vague and ambiguous term "competent authority" in this draft (current law) without any exact reference to this power, which tacitly left room for other state entities rather than solidarity device to have a legallysanctioned role in overseeing civil society that gives little cause for hope. This law was criticized under Morsi and foreign governments urge his to review it as it more oppressive to hostile to civil society groups than all laws and draft bills under Nasser, Mubarak, and the SCAF).

140. See Maha Abdelrahman, Civil Society Exposed: The Politics of NGOs in Egypt 129-31 (2004) (highlighting the debate on the relevance of the concept of political activism and civil society to social and political reform and the role play in supporting emancipatory projects and as a main engine for social and political transition).

141. See Cairo Institute for Human Rights Studies, Draft Law for the Nationalization of Civil Society and Transforming it into a Government Institution, Apr. 2012, http://eipr.org/en/press/2012/04/draft-law-nationalization-civil-society-and-transforming-itgovernment-institution (last visited Sep. 4, 2016) ("The undersigned human rights organizations declare their utter rejection of the new draft law on non-governmental organizations (NGOs), prepared by the Ministry of Insurance and Social Affairs and which aims to nationalize civil society. Under this law civil society would be considered an institution of the government, and 
is very narrow in its context, as freedom of association is very strict, and that allowed the government to use illegal devices to avert the growth and development of civil society. ${ }^{142}$ Furthermore, external pressure, mainly from Western governments, has barred Egyptian authority from completely restricting NGOs and has provided outside financial assistance to aid the NGOs' development. ${ }^{143}$ Additionally, the Egyptian government lacks the ability and resources to fully confine civil society organizations. ${ }^{144}$ Nevertheless, while policing the civil society may be an extensive and problematic mission, it would be difficult to argue that it is beyond the State's capacity. ${ }^{145}$

One of the main arguments in this respect is that the Egyptian government has followed policies that permitted the NGO sector's development as to attain the State's political objectives, while limiting them and giving itself the legal and extralegal devices to stop elements in the NGOs field from posing a threat to the State's power. ${ }^{146}$ These two-faced policies coincide with government interests, such as requiring NGOs to provide various definitive community services and

NGO staff would be regarded as civil servants. Furthermore, the new law would impose several new arbitrary restrictions aiming to terrorize civil society activists").

142. Maha Abdelrahman, The Politics of 'Uncivil' Society in Egypt, 29 REV. OF AfRICAN Political ECONOMY 91 (2002) ("It argues that the recent celebration of the concept as the domain of freedom and justice and as a panacea for the ills of state led development models has underestimated its inherent weaknesses and limitations . . Tracing the historical development of the concept ... provides an alternative view of the conflictual, often reactionary nature of civil society organizations. The Egyptian case offers empirical demonstration of how the state is no longer the prime authoritarian force in repressing civil society organization. Instead, civil society has become an arena for political conflict and its organizations have been seized by representatives of contending political programs that often resort to violence and repression to suppress other groups within civil society").

143. Id. See also Vickie Langohr, Too Much Civil Society, Too Little Politics: Egypt and Liberalizing Arab Regimes,

36 Comparative Politics 2, 194 (2004).

144. Id.

145. See Abdelrahman, supra note 142, at 160 (pointing out that according to the current NGO law in Egypt, the state has the power to:

(a) blocking of international (foreign) funding with no reasonable or legal ground;

(b) denying (rejecting) any registration or recording with arbitrary and ambiguous justifications;

(c) imposes major/massive bureaucratic clauses (surveillance and security) on NGOs to give the government the ability to crackdown on petty infarctions along with sever (criminal or civil) punishments (imprisonment and huge fines), and

(d) shut down and monitor the organizations, interfering in its governance, and security officials may attend their meetings and event in case of suspicion (threat to public order, morals, or national unity or security)).

146. Id. at 128 . 
development needs, and improving the state's image overseas, while questioning liberalism domestically. ${ }^{147}$

In summation, it should be noted that the new law's key provisions (89 articles), limits the work and the freedom of international organizations operating in Egypt. The legislation instructs that foreign NGOs interested in operating in Egypt must obtain advance approval from a new government body, the National Authority for Regulation of Foreign Non-Governmental Organizations, before beginning operations. ${ }^{148}$ Also, all foreign NGOs operating in the country are given a grace period of one year from the enforcement date of the law to complete registration with this new body. ${ }^{149}$ The law also launches a National Authority for the Regulation of Non-Governmental Organizations, which will have its own director and will include representatives from the Ministries of Foreign Affairs, Defense, Justice, the Interior, International Cooperation, and Social Solidarity, as well as the General Intelligence Services, the Central Bank of Egypt, and the government's anti-money laundering unit. ${ }^{150}$ The law sets out restrictions on how NGOs deal with received donations and funding, as NGOs may not use donated money for work related to political activities, such as funding parliamentary candidates or political parties, or for inciting hatred, spreading sectarian tension, or damaging national security. ${ }^{151}$ Donations to any NGO that amount to more than 10,000 Egyptian pounds (about \$552 USD) will need to be pre-approved, and money transfer transactions between bank accounts are subject to audits or paper checks by Egypt's Central Bank, done both by electronic means and paper record checks. ${ }^{152}$

The statute imposes penalties against violators; for instance, no NGO is permitted to carry out or publish the results of a study or survey without prior

147. Id. at 179. See also Abdalla, supra note 43 ("The Egyptian regime cannot be called authoritarian, but rather "semi-authoritarian," according to Marina Ottaway; or "liberalized autocracy," in Daniel Brumberg's phrase. That is to say, this regime is able to consolidate its authoritarianism while putting in place measures that can be considered more or less liberal. For such a system, the proliferation of NGOs is less likely to be a means of empowering groups seeking to change the regime's strategy than a part of the controlled-liberalization strategy itself. The presence of these NGOs and their various activities, even those seen as anti-government, can be viewed as outgrowths of a policy of controlled liberalization. Thus, the government has much more to do with promoting civil society than civil society has to do with democratization. This situation creates a plight for donors, who find themselves funding organizations that bolster the regime's survival strategy, rather than organizations with a realistic chance of affecting this strategy").

148. See George Sadek, Egypt: People's Assembly Passes NGO Law with Two-Thirds Advice, Global Legal Monitor (Dec. 2, 2016); George Sadek, Egypt: Parliament Provisionally Approves Legislation Regulating NGOs, Global Legal Monitor (Nov. 22, 2016). See also Law No. 70, of 2017, supra note 8, at Art. 2

149. Id.

150. Id., at Arts. $70 \& 72$.

151. Id., at Arts. $13 \& 14$. Foreign NGOs operating in the country must seek the approval of the Central Bank to open a bank account to deposit donations and funds. Id., at Art. 22.

152. Id., at Art. 22. 
permission from the government security organizations. ${ }^{153}$ Those who violate this provision could receive sentences of up to one year in prison and fines of between 20,000 and 500,000 Egyptian pounds (about \$1,100 to \$27,600 USD). ${ }^{154} \mathrm{~A}$ punishment of imprisonment for between one year and five years and a fine of between 50,000 and one million Egyptian pounds (about \$27,606 to \$55,211 USD) will be imposed on those who cooperate with foreign organizations and work in civil society without a permit and without prior approval. ${ }^{155}$ Civil society is defined under the law as all projects carried out by NGOs aimed at the development of the society. ${ }^{156}$ NGOs are forbidden from opening headquarters or offices in any province without written approval from the Ministry of Social Solidarity. ${ }^{157}$ If the headquarters of an NGO is moved somewhere other than the originally registered location without permission for the move having been obtained, the designated court will order the dissolution of the NGO's board. ${ }^{158}$

As the state is operating with no strategy or vision, the new law allows the Egyptian government to jeopardize the receipt of a portion of the annual U.S. aid to Egypt. ${ }^{159}$

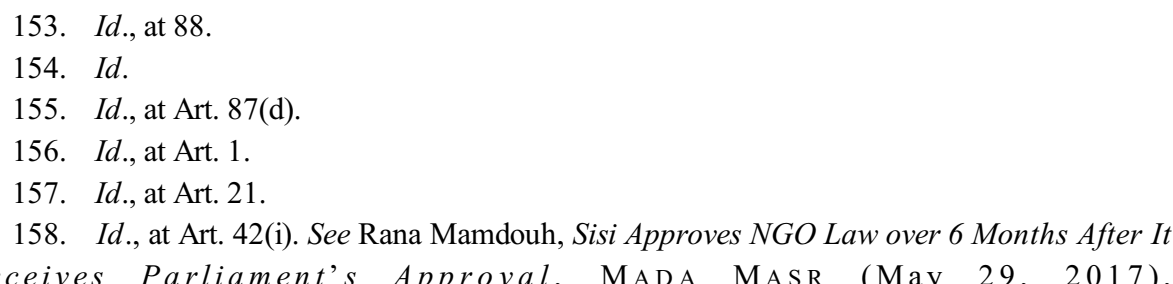
Receives Parliament's Approval, MADA MASR (May 29, 2017), https://www.madamasr.com/en/2017/05/29/feature/politics/sisi-approves-ngo-law-over-6-monthsafter-it-receives-parliaments-approval/ ("The law was 'cooked up' in four hours and took six months to be approved," ... affirming that members of the 25-30 Coalition continue to oppose the law, even after its approval. The law makes provision for the creation of a new national authority — the National Authority for the Regulation of Non-Governmental Foreign Organizations whose mandate will extend beyond monitoring foreign organizations to include monitoring all NGOs who receive funding from international sources and verifying that these organizations are spending the money they receive in approved ways. The law also stipulates that the authority must be notified about local funding sources. The National Authority for the Regulation of NonGovernmental Foreign Organizations is to be formed through presidential decree, will be headed by a full-time president, [...] despite the Trump administration's request for $\$ 1.3$ billion in military aid to Egypt, it remains up to congressional appropriators whether Egypt receives this aid, and what conditions need to be met before it is released. US Senator Lindsey Graham, a key member of the US Senate Appropriations Committee, strongly criticized the NGO law in December, threatening: "Should President Sisi sign into law this draconian legislation, we will endeavor to strengthen democratic benchmarks and human rights conditions on US assistance for Egypt in fiscal years 2017 and 2018." The Egyptian government has severely restricted the space for human rights work, issuing numerous travel bans on rights workers and reopening investigations into the NGO foreign funding case, which had been dormant since 2011").

159. The Deputy Director for Policy at the Project on Middle East Democracy (POMED, a nonprofit organization), Cole Bockenfeld, stated that " $15 \%$ of U.S. government aid is conditional on whether the government of Egypt impedes the ability of civil society organizations and the 


\section{THE REAL CHALLENGE: DIAGNOSES AND SCENARIOS FOR TRANSITIONAL REFORM: CONCLUSION, KEY FINDINGS, AND POLICY RECOMMENDATIONS}

Historically and practically, the relationship between the State and the civil society organizations, along with the NGOs' activities, were based on manipulation, oppression, and tyranny. However, Egypt's uprisings sparked hope and a desire for change and legal reform of the various restraints on NGOs. ${ }^{160}$ However, the enormous bureaucracy regulating NGOs presents an obstacle to legal reform. This bureaucracy is furthermore willing to transgress the law and exercise its discretionary power to control civil society undertakings and hinder NGOs that it views as menaces. ${ }^{161}$

Egypt's revolts in 2011 and 2013 opened the door for legal alteration and the new contemporary Egyptian government appears more receptive to the international pressure than the previous régimes, which may lead to a shift in the nature of State's treatment of NGOs. ${ }^{162}$ There are inconsistencies between the despotic nature of the government and the vitality and size of the civil society. Internal and external pressure may partially clarify why the Egyptian government permitted the NGO sector to cultivate. ${ }^{163}$ Egypt's previous régimes have been able to avert and ban the work of these organizations - specifically the human rights agencies - by controlling them to ensure that their work in no way threatened

media to operate freely without any government pressure." He also stated that "it is up to the discretion of the U.S. Secretary of State to either waive these conditions in order to release this portion of the aid or to enforce them and suspend the assistance. See Egypt's Sisi Approves Controversial NGO Law, ALJAZEERA (May 29, 2017) (“Gamal Eid, a human rights lawyer, stated that "[t]he law eliminates civil society in Egypt, whether human rights or development organizations"). See also Egypt Approves Draconian NGO Law Targeting Civil Society, AL-ARABY (May 30, 2017), https://www.alaraby.co.uk/english/news/2017/5/30/egypt-approves-draconian-ngolaw-targeting-civil-society ("Egypt program director at the Cairo Institute for Human Rights Studies told Reuters that the new law was the "worst in history" and would effectively ban NGOs from carrying out their work. No organization will be permitted to carry out or publish surveys or studies without prior permission from the state.").

160. Ahmed Hussein, Social Reform in Egypt, With Special Reference to Rural Areas, 44 THE MUSLIM WORLD 1, 12- 19 (1954) (discussing the social reform in Egypt and focusing on the ultimate goals of achieving prosperity, social justice, and social security).

161. Denis J. Sullivan, Private Voluntary Organizations in Egypt: Islamic Development, Private Initiative, and State Control, FlORIDA UNIV. PRESS 13 (1994) (explaining that "grassroots groups are a significant--and largely ignored--part of the development process. Approximately 14,000 PVOs are registered with the Ministry of Social Affairs in Egypt, including groups affiliated with religious, feminist, labor, capitalist, and human rights organizations. They respond primarily to the needs of individuals and communities that suffer from government mismanagement of the economy and from state control of social and political activities ...").

162. Hussein, supra note 114. See also Abdalla, supra note 43.

163. McGann, supra note 135. 
state supremacy. ${ }^{164}$

Accordingly, it is essential to develop civil organizations' role in political, economic, and social transformations. Rather than looking at the NGOs' number or the periodic confrontations between the government and these groups in order to judge NGOs' capability to check on state's power. ${ }^{165}$ It is important to look closely at the physical (structural) matters, legal agendas, and the techniques the government could deploy on NGOs to improve and advance their own interests. ${ }^{166}$ It is important to see how much improvement the Egyptian government will make regarding this sector and its operations, but it is also important to assess the progress level of civil society towards its autonomous and self-independent nature, since it can check the State's authority. ${ }^{167}$

Now is the time for Egypt to reevaluate the destabilizing policies that it imposes on the civil society sector. New efforts to assist civil society in Arab countries, especially Egypt, as a heart policy in the Middle East should focus on: (a) assisting civil society associations that could play a crucial role in political change (human rights and democratic reform issues); (b) categorizing support for NGOs as socio-economic development (healthcare, employment, education, etc.); (c) evading the continuous constricted (narrow) focus on the normal suspects and implementing communication and cooperation channels to new sectors of civil society, such as democratic assemblies, qualified establishments, moderate Islamic groups, political liberalization and informal civil society organizations; (d) developing more tactical ways for NGOs to help as donors and improving programs that promote the motives of civil society organizations' willingness (addressing the oppressive legal frameworks), sustaining prospects for crosssector alliance, reinforcing civil society self-sufficiency as a priority by evading strategies that let governments control their funding or activities, helping NGOs

164. Id.

165. See Mariz Tadros, The Securitization of Civil Society: A Case Study of NGOs-State Security Investigations (SSI) Relations in Egypt, 11 Conflict, SECurity, \& Development 1, 79 103 (2011) (exploring the reforming role of the state security apparatus faced with external pressures to democratize) ("It argues that in Egypt the State Security Investigations (SSI) has played a dual role of repressing opponents while creating and mediating political space for citizen voice and participation, eliciting a positive external image without representing a genuine threat to the regime. The SSI's role in civil society has expanded significantly, in particular since the mid2000 s, and its power is now exercised not only in a hidden form but also in a very visible manner. An increase in the SSI's visibility has increased its exercise of a more pervasive form of invisible power, as is evident from the examination of current SSI-NGO relations").

166. Id.

167. Amy Hawthorne, Middle Eastern Democracy: Is Civil Society the Answer? MidDLE EAST SERIES, CARNEGIE ENDOWMENT 6 (2004), http://carnegieendowment.org/files/CarnegiePaper44.pdf (“After Arab countries gained independence, a restrictive third phase began. New regimes feared that pluralistic, independent associative life would undermine national unity, and threaten their own attempts to consolidate power. Thus, independent civic activity was brought under tight state control as civil society organizations were transformed into state-dominated institutions or were repressed"). 
develop policies for raising community funds, and reducing reliance on government subsidies; (e) legalizing new political parties, holding more competitive elections, and lifting press and media restrictions; (f) dodging cookiecutter procedures and involving NGOs more expansively in needs valuations, program design, and assessment; and finally (g) strengthening themes of civil society to aid the diplomatic perspective. ${ }^{168}$

Building and supporting healthy civil societies abroad is more problematic than it might seem because civil society is likely to play a more modest role in democratization than is often expected. Therefore, providing assistance will require law reformers and policymakers, along with financial aid providers, to show a level of endurance, flexibility, and knowledge on local history, language, traditions, and cultures. Strong and successful civil society support requires viable cooperation, trustworthy partnerships, and a vision for comprehensive reforms that are shared by donors and civil society organizations to tackle the problems lying ahead for the society's mutual and common benefits.

168. See generally Laith Kubba, The Awakening of Civil Society, 11 J. of Democracy 3, 84-90 (2000) ("For more than three decades, Egypt, Syria, and Iraq had functioning democracies in which deputies were elected, government officials were held accountable to laws and rules, the judiciary was independent, the press was free, and the people enjoyed equality before the law and basic civil and human rights"). 